\title{
How does Governmental vs. Private Venture Capital Backing Affect a Firm's Efficiency? Evidence from Belgium
}

\author{
Yan Alperovych \\ EMLYON Business School \\ 23, Avenue Guy de Collongue, CS 40203 \\ 69134 Ecully cedex, France \\ Tel. +33 (4) 72182911 \\ Email: alperovych@em-lyon.com
}

\author{
Georges Hübner \\ University of Liège - HEC Management School \\ Maastricht University, and Gambit Financial Solutions \\ Liège 4000, Belgium \\ Tel: +32 (4) 2327428 \\ E-mail: g.hubner@ulg.ac.be
}

Fabrice Lobet

Free University of Brussels

Brussels 1050, Belgium

Tel: +32 (2) 6504139

E-mail: flobet@ulb.ac.be

October 27, 2014 


\begin{abstract}
This paper investigates the implications of the venture capital (VC) investor type (government or private) on the operating efficiency of a sample of 515 Belgian portfolio firms up to three years after the investment. We show that within a pool of VC-backed firms, the targets of the government VC display significant reductions in productivity. No significant differences in efficiency are found in firms backed by private $\mathrm{VC}$ compared to their non-VC-backed peers. Finally, significant reductions of efficiency are still present in targets of government $\mathrm{VC}$ compared to their non-VC-backed peers.
\end{abstract}

Keywords: Venture Capital; Efficiency; DEA; Fund type; Public investor.

JEL classification: G24, G30, M13, O16.

\title{
1 Introduction
}

Despite the seemingly modest volumes of venture capital (VC) investments in comparison to the rest of capital flows, the consequences of such financing are quite substantial (Lerner, 1999, 2002b, 2009). In terms of innovation, Kortum and Lerner (2000) find that VC-backed firms are characterized by significantly higher patenting rates in comparison to their non-VC-backed peers. In the same vein, Davila et al. (2003) find a positive relationship between the growth of start-ups, as measured by the labor growth, and the VC funding. At the macroeconomic level, Samila and Sorenson (2011) document a highly positive impact that the supply of VC has on business creation, employment, and aggregate income in the US. In terms of performance, VC-backed firms display better chances of IPO and survival rates after an IPO (Hochberg et al., 2007; Puri and Zarutskie, 2012). The operating performance of VC-backed firms also seems to be superior to the performance of comparable non-VC-backed companies (Alperovych and Hübner, 2013). These arguments outline the existence of the added value of venture capital financing.

Many governments sharing this conviction about the benefits of $\mathrm{VC}$ activity have introduced programs to foster venture capital financing. These initiatives may take three general forms: regulatory framework ("law"), indirect framework, and direct investment schemes (Keuschnigg and Nielsen, 2001; Cumming, 2007; Cumming and Li, 2013). The "law" mainly relates to taxation and institutional frameworks in which venture capitalists and entrepreneurial firms operate. Indirect frameworks include programs that favor technology transfers from universities to business, creation 
and support of business incubators, and structuring industrial sectors in clusters. Finally, the "direct investment schemes" mainly focus on the supply side of the market. These schemes may be broken down into three types: (i) the guarantee system, in which the government commits to covering, totally or partially, potential losses of private $\mathrm{VC}$ funds, (ii) the fund-of-funds system, where the government co-invests together with private VC funds, and (iii) the direct investments in small and medium enterprises (SMEs) by government-sponsored venture capital (GVC) investment funds. In this paper, we focus on this third vector of public influence in the $\mathrm{VC}$ world. ${ }^{1}$

Various studies have investigated country-specific settings of different forms of governmentsponsored VC, as in the US (Lerner, 1999; Cumming and Li, 2013), Canada (Cumming and MacIntosh, 2003, 2006, 2007), UK and Germany (Cumming, 2003; Heger et al., 2005; Sunley et al., 2005; Bascha and Walz, 2006), Australia (Cumming, 2007; Lerner and Watson, 2008; Cumming and Johan, 2009), Finland (Maula et al., 2007), and on a pan-European basis (Leleux and Surlemont, 2003; Rin et al., 2006; Cumming et al., 2013). International evidence of the effects of GVC on investment patterns and exit performance is documented by Cumming et al. (2013) and Brander et al. (2014).

None of the aforementioned papers investigates the transformation process of inputs into outputs (i.e. the firm's operating efficiency). Rather they focus on GVC-funded firms' output levels such as growth in sales revenues and/or labor, patents, returns, or exit patterns. Yet efficiency is a substantial determinant of firm performance (Bottazzi et al., 2008a), and there is recent evidence that it is itself positively impacted by VC backing (Chemmanur et al., 2011; Croce et al., 2013). One may thus wonder where the source of this impact comes from. Our paper contributes to answering this question. Using the case of Belgium, we investigate whether the impact of investor type can be observed upstream from the output, directly in firm productivity. Specifically, we use operating efficiency as a metric in order to contribute to the debate on the impact of $\mathrm{VC}$ funds' "origin" - government or private - on firm performance.

Just as private $\mathrm{VC}$ investors, GVC funds face the issues of selection of right targets, and coach-

\footnotetext{
${ }^{1}$ See Lerner (1999), Keuschnigg and Nielsen (2001), and Lerner (2009) for an extensive discussion on the theoretical rationale for public intervention in the $\mathrm{VC}$ industry.
} 
ing portfolio firms in their growth and development. Even though their global objective is probably not only profit maximization, but also job creation and stabilization of regional economic activity, ensuring that the provided funds are properly allocated and used efficiently by their portfolio firms is still incumbent upon the management of such funds. In light of the recent criticism that governments often fail in this task (Shane, 2009), a thorough analysis of the implications of GVC financing on efficiency becomes worthwhile and instructive. Our general research question is therefore formulated as follows: How do differences in types of venture capital investors (GVC/PVC) affect the post-investment efficiency of their portfolio firms?

To address this question, we have gathered data on 515 Belgian venture capital deals during the period 1998-2007. To enhance our analysis, we subsequently investigate the question whether VC-backed firms in Belgium are more or less efficient than their comparable non-VC-backed (NVC) peers, again focusing on the GVC-PVC investor dichotomy. For this purpose, we start from the entire population of Belgian firms to construct the control group of similar firms that are not subject to any form of VC financing.

To estimate efficiency, we rely on Dynamic Data Envelopment Analysis (DDEA) models (Färe and Grosskopf, 1996; Tone and Tsutsui, 2010). Rooted in the data envelopment analysis (DEA) literature, it draws on the microeconomic theory of firms' optimizing behavior. In this sense, it has stronger theoretical foundations than accounting ratios (Cook and Seiford, 2009). Practically speaking, for each VC-backed or comparable firm, we estimate a global efficiency score, bounded between 0 and, 1 over the four year time window spanning from the pre-transaction ${ }^{2}$ year to three years post-transaction. The higher the score, the more efficiently a firm uses its inputs to produce outputs. The global efficiency score is then decomposed into term efficiencies, which show the evolution of efficiency over time. We next use the estimated scores in a regression setting to assess the impact of the VC investor type on the efficiency of the firm.

Our findings indicate that within the cohort of VC-backed firms, efficiency increases following the VC injection. This result, however, is not uniformly split between GVC- and PVC-backed portfolio firms. The univariate global, as well as the term efficiency scores, show that Belgian

\footnotetext{
${ }^{2}$ The terms transaction, injection, or deal are used interchangeably and denote the time of $\mathrm{VC}$ investment.
} 
GVC-backed firms lag behind their privately-backed peers in terms of productivity. Having a GVC investor in the firms' equity results in substantial reductions of global efficiency over the four year study window. Factoring comparable NVC-backed firms into the analysis suggests that GVC-backed portfolio companies lag even behind their comparable peers. At the same time, we find no effect of PVC funding on productivity, when compared to the NVC-backed firms. ${ }^{3}$

These results shed new light on existing evidence on the impact of VC financing on efficiency, and sometimes contradicts it. The study by Chemmanur et al. (2011) suggests that VC-backed firms are more efficient than non-VC-backed firms both prior and after VC financing. Our results show that the differential effect of VC backing in Belgium mostly results from productivity destruction from GVC rather than an improvement due to PVC. Besides, we confirm the documented findings that VC improves the productivity of the targets after the first financing event, consistent with Croce et al. (2013). At the same time, the type of VC clearly matters as well. Being financed by a GVC fund seems hinder this improvement in productivity, firm's efficiency remaining below even the level of NVC-backed firms.

The remainder of the paper is organized as follows. Section 2 presents the theoretical design. Section 3 outlines the methodology and data used in the analyses. Section 4 presents the results. Finally section 5 concludes.

\section{Background and theoretical design}

\subsection{Venture capital financing and efficiency}

A large body of the literature posits that besides returns (Cochrane, 2005; Hand, 2007; Korteweg and Sørensen, 2010), VC also stimulates growth, spurs innovation, and creates jobs both at firm

\footnotetext{
${ }^{3}$ A plausible counter-argument may suggest that since GVC funds have objectives like job creation and stabilization of the economic environment, it is inappropriate to make cross-firm comparisons on the basis of productivity only. To an extent, we counter this with a side examination of the job creation with respect to the investor type. These analyses indicate that GVC-backed portfolio companies failed to create more jobs than their privately-backed peers with the resources at their disposal. This indicates that the capacities of generating added value and creating more jobs complement each other, and are not substitutable in our sample and echoes the theoretical ideas of Jovanovic (1982), who suggests the positive link between the efficiency, survival, and growth of firms. Due to space limitations we do not present these results in the main text but they are available upon request.
} 
and economy levels (Kortum and Lerner, 2000; Samila and Sorenson, 2011; Puri and Zarutskie, 2012). The mechanisms through which VC financiers produce value are selection and value adding (Alperovych and Hübner, 2013). First, VC investors carefully pick their targets using stringent screening criteria Tyebjee and Bruno (1984); Macmillan et al. $(1985,1987)$ and scrutiny in the selection process. This allows them to significantly reduce the information asymmetries around potential qualifiers prior the initial investment (Lerner, 2002b; Knockaert et al., 2006). Second, VC investors closely monitor, control, and involve themselves actively in their portfolio firms after the financing takes place (Sapienza et al., 1994; Bottazzi et al., 2008b). Monitoring and control efforts by VC investors include (but are not limited to) the board representation (Lerner, 1995), staging of capital infusions (Lerner, 1995; Cornelli and Yosha, 2003), and use of convertible securities to name but a few (Hellmann, 1998, 2006). Similarly, advisory and involvement services could involve the internal restructuring of the management teams and their compensation structures (Sapienza, 1992), assistance in the strategic and operational management (Hellmann and Puri, 2000), professionalization, headhunting and additional fundraising (Hellmann and Puri, 2002). VC investors also heavily capitalize on their network of contacts to enhance the scale and empower the growth of the ventures they fund (Hsu, 2000; Davila et al., 2003; Hochberg et al., 2007). Finally, the reputation and experience of $\mathrm{VC}$ sponsors play a critical role in facilitating growth and certifying the quality of a venture (Gompers, 1996; Sørensen, 2007). Combining these effects results in a more efficient allocation of resources, which implies improvements in a firm-level productivity and thus superior efficiency of VC-backed firms (Chemmanur et al., 2011; Croce et al., 2013).

\section{$2.2 \quad$ Venture capital investor type and efficiency}

Improvements in productivity (as well as other benefits) can only be achieved if screening and value added mechanisms are properly implemented and enforced. This translates into constraints $\mathrm{VC}$ funds are subject to. These latter, however, may vary depending on the type of $\mathrm{VC}$ investor (Lerner, 2002b).

PVC investors are subject to strong contractual, financial and reputation constraints coming 
from the institutions (called limited partners, LPs) VC firms raise money from (Florin, 2005; Bottazzi et al., 2008b). Contractual pressure is related to the complex partnership agreements, which govern the business relations between LPs and managers of VC funds. Gompers and Lerner (1996) characterize three broad classes of restrictions (covenants) pertaining to the overall fund management, to the activities of fund managers, and to the types of targets in which the fund is allowed to invest. Violation of these clauses results in penalties applied to PVC fund managers, which limits the potential for agency conflicts and costs associated with them.

Financial pressure is related to the strong return requirements and compensation structures. Return hurdles, coupled with a fund's limited lifetime forces fund managers to discontinue the financing of underperforming investments and adopt a clearly observable exit-oriented investment strategy (Gompers and Lerner, 2004; Lerner et al., 2007). At the same time, the compensation structures of PVC funds (management fees and carried interest) are closely linked to the outcomes of their investments policies (Jensen, 1986; Gompers and Lerner, 1999; Metrick and Yasuda, 2010). This also should force the fund managers to exert a considerable effort in selection, monitoring, and value-adding activities (Sapienza, 1992; Sapienza et al., 1996; Bottazzi et al., 2008b).

Reputation pressure is related to violations of the contractual agreements and failures to deliver sufficient financial returns to limited partners (LPs). Since VC investors recursively raise funds as part of their business activity, LPs are unlikely to commit their capital to a VC firm with a poor track record (Gompers, 1996; Gompers and Lerner, 1999). Such constraints force PVC managers with limited financial and overseeing resources to ensure that funds they provide to the entrepreneurial firms are properly allocated, and that moral hazard problems at the investee level are addressed, in order to maximize the overall exit value of their portfolios (de Clercq and Manigart, 2007).

GVC funds are largely exempt from such pressures. In general, they use or leverage public money for their operations and their lifetime is often unlimited. Although it is possible that these funds have statutory life-span limitations, Lerner (2009) argues that once introduced, these funds often become very difficult to "kill off". Their activity is unlikely to be governed by a limited partnership-like agreement. They are not subject to stringent financial return requirements and 
have no clearly defined exit strategy. Finally, they are unlikely to bear reputation constraints and thus they do not need to worry about raising follow-on funds.

Managers of GVC funds, often civil servants, typically have an extensive experience in retail credit sectors, law, audit, and financial analysis. This automatically translates into a selection process more akin to the credit risk acceptance. As a consequence, GVC funds are also much less streamlined on particular (high growth) industries, and are prone to invest into traditional sectors with more stable cash flows. Furthermore, stand-alone GVC funds (see Appendix B.1 for a background on the Belgian VC Industry and the description of major GVC funds) are not used to setting up performance-based compensation structures similar to those of private venture capitalists (Manigart et al., 2002). As a consequence, their managers are less likely to have incentives to select best possible targets and to put pressure on their portfolio firms and maximize the exit value of their investments (Leleux and Surlemont, 2003).

The combination of these factors should undermine the effectiveness of the selection, monitoring, and control mechanisms. In fact, the overall objectives of GVC funds might be different and consist in the regional economic development (which has a longer horizon) and job creation. Even though this goal is legitimate, government agents could allocate funds in a less efficient way (Lerner, 2010), and approve investments in non-profitable projects (Lerner, 2002b).

On balance this suggests that the operating mode of PVC funds could lead to a more productive resource allocation and consequently to more efficient targets. Therefore our main hypothesis on the efficiency of Belgian VC-backed firms suggests that firms backed by $P V C$ funds will be more efficient than their peers backed by GVC funds.

\section{Methodology and data}

\subsection{Methodological approach}

To measure efficiency, we use slacks-based dynamic data envelopment analysis (DDEA) models (Tone and Tsutsui, 2010). Originally, the data envelopment analysis (DEA) methodology was 
designed to evaluate a firm's productivity with respect to the best firms in a reference group (Charnes et al., 1978; Cooper et al., 2007; Cook and Seiford, 2009). The idea of measuring efficiency relatively to a benchmark can be traced back to Farrell (1957) and Debreu (1959). One can in principle define efficiency as the ability to produce a maximum possible output given a mix of inputs. Assuming that the form of the optimal production function is known, an efficient frontier of production possibilities for all input mixes can be constructed. The more efficient the firm is, the closer it is to the frontier. Unfortunately, the optimal production function is not known. In this context, Farrell (1957) suggests to (i) assume a theoretical one, like the Cobb-Douglas production function, or (ii) rely on an empirical one based on the "best results observed in practice". DEA follows the second venue evaluating the efficiency of firms relative to the "best practices production frontier".

In the seminal paper by Charnes et al. (1978) suggested to measure efficiency of any firm as "the maximum of a ratio of weighted outputs to weighted inputs subject to the condition that similar ratios for every firm be less than or equal to unity". The efficiency of a given firm is then measured with respect to the reference set (other sample firms). Within this reference set, DEA defines the best performers, which form the efficient frontier and have the efficiency score equal to one. Remaining firms are benchmarked relative to this frontier and receive a score between 0 and 1. This can be illustrated using the following example. If a firm A belongs to the set of best performers, there is no firm B in the sample, which can produce more than A, provided that the combination of B's resources is not greater than the combination of resources of A. If B uses more resources than $\mathrm{A}$, and achieves higher output levels, then $\mathrm{B}$ can belong to the set of best performers. But this is only possible if there is no firm $\mathrm{C}$, which produces more than $\mathrm{B}$ using the same or lesser amount of resources as B, and so on. Obviously, the set of best performers will include many firms, but none of them will be "outperforming" one another, because their relative efficiencies are equivalent. The DEA efficiency score is in this context a distance measure, expressed in percentage terms, indicating how far efficiency-wise a given firm is from the frontier. DEA has several advantages over the traditional regression-based models. It allows for the concurrent use of multiple inputs and outputs, resulting in a more accurate consideration of pro- 
ductivity. It draws on the microeconomic theory of firms' optimizing behavior and in this sense has stronger theoretical foundations than accounting ratios, often used in performance studies. Furthermore, DEA requires no statistical assumptions about the nature of production technologies that convert inputs into outputs, which contrasts with other studies that use total factor productivity (Lichtenberg and Siegel, 1990; Harris et al., 2005; Chemmanur et al., 2011) and stochastic frontier modeling (Amess, 2003). For this reason DEA models are not subject to the misspecification errors (Gregoriou et al., 2005).

The advantages of DEA come at some costs. Since the point here is the application of the DEA, we discuss the difficulties in the empirical implementation rather than theoretical limitations. First, DEA does not allow for the missing data. A more delicate issue is the negativity in the data. As a general rule, all input and output data is bound to be nonnegative, although slight modifications to account for the negative data are available for some DEA models. Second, there is an important trade off in terms of the number of observation units vs. number of inputs/outputs. Having too few firms, keeping the number of inputs/outputs fixed, results in too many DMUs being classified as efficient. Conversely, having too many firms results in most of them being inefficient with a zero score.

Original DEA models are cross-sectional. Many applications, however, are more insightful in a longitudinal context, which is why further theoretical advances have enabled an explicit incorporation of the continuous time structure into efficiency measurements (Färe and Grosskopf, 1996; Chen and van Dalen, 2010). One of the latest developments in this field is the dynamic slacks-based measure (DSBM) developed by Tone and Tsutsui (2010). We use the input oriented DSBM model to evaluate efficiency over a four year window between the pre-transaction year (injection year for startups) $T-1$, and three years after the transaction $T+3$. To avoid the endogeneity issues, inputs are always one year lagged with respect to outputs. Using these models enables us to explicitly account for management's optimizing behavior over time. As a result, for each sample firm we observe how efficient (productive) it was over this period in comparison to its direct peers. This information is summarized in the global efficiency score. The latter can also be decomposed into the term efficiencies (three in our case), which illustrate the path efficiency 


\footnotetext{
${ }^{4}$ The action of the policy makers is limited to the definition of the strategic orientations, endowment decisions, and the monitoring of funds' activities (often very light and no penalties are applied). Once set up, the funds generally benefit from a wide autonomy of action. They are all incorporated as commercial companies subject to public law. Political parties usually have a seat on the board and could affect some more operational decisions. However, their influence could be possibly counterbalanced by other directors that come from the private sector. One exception is the Walloon SRIW that operates, beside its classical role of an autonomous GVC fund, as the financing tool of the Walloon Government. This function is limited to specific cases such as the recapitalization of distressed financial institutions in September 2008.
} 
period under study. The effects of the main GVC options while supporting investments in the SME segment can thus be measured on a similar basis.

Data from different secondary sources were combined to construct the raw dataset. We started by recording first round VC-backed deals in Belgium using Factiva, various news archives, VC funds' annual reports, press releases, newsletters, and announcements. In order to ensure the validity of the observation units, we manually cross-checked, whenever possible, each hit between the mentioned sources and Venture Economics, Capital IQ, and/or Bureau Van Dijk's Zephyr databases. Each entry of the raw data contains information on the year of financing round $(T)$, the type of round (we focus on early- and development capital stages only), the target's identification number (VAT number), and the type of sponsor. The total number of unique first time financings in this raw dataset is 1030 . To verify its completeness, we cross-checked it with the yearbooks of the European Venture Capital and Private Equity Association (EVCA). EVCA collects information (on a voluntary basis) directly from investors and disseminates the industry statistics. Although we cannot rule out the potential self-reporting bias in EVCA's data, these reports have been extensively used by researchers as the benchmark of Belgian VC population (Manigart et al., 2002; Chanine et al., 2007). According to EVCA, the number of Belgian first-round injections during the period 1998-2007 was 1162 (EVCA, 1998-2007). Note that these records include replacement and turnaround deals, management buyouts and investments in financial \& real estate sectors. Our set roughly accounts for about $90 \%$ of the population described by EVCA. Considering this, we believe our data is fairly representative of the Belgian VC industry.

We recover firms' annual financial statements, creation dates, and industrial sector codes from Bureau Van Dijk's Bel-first database. Since our focus is on the young entrepreneurial ventures we drop firms from financial and real estate sectors, and those that are over ten years old. All monetary data was adjusted for inflation (base year 2004). Because of the large amount of missing data introduced by Bel-First our final sample, denoted the base sample (BS), consists of 515 VCbacked companies (with injection years spanning 1998-2004) for which we have complete data to perform all efficiency estimations over complete cycles of 4 years. ${ }^{5}$ The details about the treatment

\footnotetext{
${ }^{5}$ In earlier versions of the paper, we used a five-year time frame, which is consistent with a median holding period
} 
of missing data are available in Appendix B.2.

Panel A of Table 1 presents the broad industry distribution at the two-digit NACE-BEL 2008 level of the VC-backed firms. In general, investments are heavily concentrated in the high-tech and services sectors (more than 50\%). Tabulation of the investment patterns categorized by the type of investor reveals that this concentration is only relevant for the PVC. GVC funds mostly invest in traditional sectors like construction, manufacturing, and HORECA. An intuitive interpretation might be that public funds having lower knowledge and experience choose targets from the traditional industries. This may be also paralleled with the anecdotal evidence that most of the members of the investment committees of public funds are former bankers and auditors. Consequently, they could have preferences for firms with more stable and secure cash flows. Alternatively, this structure could also be an illustration of the money-chasing-deals phenomenon (Gompers and Lerner, 2000), and/or of the self-selection of high growth potential targets into the private and reputable VC companies (Hsu, 2004; Sørensen, 2007).

Panel B1 displays the first round investment patterns categorized by injection years. As one would expect, the first round investments in Belgium followed an increasing trend until the dotcom crisis in 2000. Interestingly, while we observe the decline in PVC investments after 2000, it is simultaneously accompanied by the growth in GVC funding. This seems to be in line with the premise that GVC funds are supposed to be countercyclical and provide capital to SMEs in bad times when PVC contract their investments.

\section{Table 1 HERE}

Productivity patterns can be industry-specific especially considering the differences in the capital-intensive and labor-intensive industries. Therefore, and similarly to Chemmanur et al. (2011) and Croce et al. (2013), we estimate efficiency separately for each industry sector (2-digit level).

With the BS we can only evaluate efficiency of the treated (i.e. VC-backed) firms. Another interesting question is what would be their efficiency when compared to the counterfactual firms. To for the EU countries (Cumming et al., 2013) but reduces the sample size. Our analyses yielded results consistent with findings presented here. 
investigate this second matter, we constructed a sample of control firms using the genetic propensity score matching algorithm with 1-to-1 matching without replacement (Diamond and Sekhon, 2012). Genetic matching is an iterative goal-seeking process, in which a better post-matching covariate balance is the objective. Diamond and Sekhon (2012) present it as the generalization of the standard propensity score matching procedure (Rosenbaum and Rubin, 1985; Dehejia and Wahba, 2002).

A set of possible counterfactuals is required for the implementation of the genetic matching algorithm. To construct this set, we started from the entire population of Belgian privately-held firms (excluding the VC-backed ones). The procedure goes as follows. Each firm in the BS was first matched to its respective industry (3 digits of NACE-BEL 2008 classification). Within a given industry, we located the empirical decile to which a focal VC-backed firm belonged. Following Barber and Lyon (1996), this decile was defined on the basis of total assets, in the year before the venture capital injection took place $(T-1)$. Next, for a given VC-backed firm, the set of potential counterfactuals was defined as the union of the obtained and two adjacent deciles. If the focal firm belonged to the first/last decile of its industry then first/last three deciles were taken respectively. We repeated this sequence for each VC-backed firm in the BS which gave a large pool of possible counterfactuals of similar size in the year immediately prior to VC financing. Finally, we used the logistic specification of the following propensity score model to define the matches:

$$
\begin{aligned}
\operatorname{Pr}\left(\mathrm{VC}_{i}=1 \mid X_{T-1, i}\right) & =\beta_{i}+\beta_{1} \text { Fixed assets }+\beta_{2} \text { Headcount }+\beta_{3} \text { Value added }+\beta_{4} \text { Equity }+\beta_{5} \mathrm{ROA}+ \\
& +\beta_{6} \text { Herfindahl index }+\beta_{7} \text { Crude efficiency }+\beta_{8} \text { Fundraising }+\beta_{9} \text { Investments }+ \\
& +\beta_{10} \text { TS exits }+\beta_{11} \text { IPO exits }+\beta_{12} \text { Hightech dummy }+ \text { Year dummies }+\epsilon_{i},
\end{aligned}
$$

where $\mathrm{VC}_{i}$ is the treatment indicator for a firm $i$. All regressors are measured in the pre-transaction year $T-1$, and winsorized at $1^{\text {st }}$ and $99^{\text {th }}$ percentiles. The following section provides formal definitions of the variables. 


\subsection{Variables}

\subsubsection{Variables for efficiency measurements}

In the logic of DDEA, a decision making unit (i.e., a firm) uses inputs to produce outputs in each period. Periods are connected via the links, which can be desirable (profits) or undesirable (production waste), free (unconstrained) or fixed (totally constrained). Desirable links are treated as outputs, while undesirable links as inputs. Fixed and free links do not enter into efficiency score calculation directly but affect it via the constraints set (see Tone and Tsutsui (2010) for the discussion). In our analyses of efficiency, we use the input oriented DSBM model with one output, two inputs and one desirable link measure.

We approximate the usual production factors by the number of employees (Headcount) for labor and by the net fixed assets (Fixed assets) for capital. Consistent with the premise that management should maximize shareholder value, the desirable link measure is the book value of equity capital (Equity) defined as the sum of issued capital and all reserves of the firm. Output is measured with the value added (Value added) variable computed as annual revenues less costs of production (costs of goods sold). We use value added because sales revenues are not a mandatory disclosure item for the unlisted firms in Belgium. ${ }^{6}$ All mentioned measures are commonly used in studies on productivity analysis (Lichtenberg and Siegel, 1990; Amess, 2003; Harris et al., 2005; Chemmanur et al., 2011; Alperovych et al., 2013; Croce et al., 2013). To avoid extreme values, the production factors are winsorized at the $1^{\text {st }}$ and $99^{\text {th }}$ percentiles.

\subsubsection{Variables for regression analyses}

The general variable of our interest is a dummy that takes the value of one when a private investor injects funds in an entrepreneurial firm at the first financing round (PVC). Note that this variable will be equal to one even when public and private investors syndicate. This is not necessarily an issue as there are reasons to believe that in such cases the leading role would be borne by the

${ }^{6}$ Note that value added can be negative, which poses difficulties for the efficiency estimation. To avoid negativity in outputs, Tone (2001) suggests replacing the negative items by $1 / 10$ of the smallest positive value of the corresponding output. We follow this approach and correct negative values of the VA for the efficiency estimations. 
private investor (Lerner, 1994; Lockett and Wright, 2001; Brander et al., 2002). ${ }^{7}$

Our data enables us to distinguish between the investments undertaken by major GVC players in Belgium - SRIW, the INVESTS, and other GVC investors, which include SRIB (Brussels regional fund), LRM (Limbourg regional fund), and some other GVC firms. Corresponding dummies were created for each of these cases. For the sake of comparison, we also created the dummy for GIMV - a former GVC investor. We also include a dummy for Syndication taking the value of one when the deal is syndicated. Another deal-related control that may impact on efficiency changes postfinancing is the number of financing rounds (Number of rounds) secured by a VC-backed firm after the initial capital injection.

At the firm-level we control for the age at the time of financing (Age), the initial profitability (ROA, measured as EBIT over total assets in the pre-injection year), and initial financial leverage (Leverage, defined as the sum of financial debt normalized by total assets in the pre-injection year). To control for the firms industry's concentration we construct the Herfindahl index in the same way as Chemmanur et al. (2011). Lastly, we include industry controls in the main regression models.

\subsubsection{Variables for propensity score matching}

The first VC funding round is defined as a dummy "VC". To estimate the propensity score we use several firm and VC industry level covariates all measured in the pre-investment year. The net fixed assets, number of employees, value added, shareholders capital, return on assets, and Herfindahl index have been already defined above. We add a crude measure of initial efficiency (Crude efficiency) computed as the value added over the number of employees.

The literature identifies several measures of the VC industry conditions as having an impact

\footnotetext{
${ }^{7}$ It is worth noting a growing strand of literature highlighting a positive impact of mixed syndicates by GVC and PVC investors on various performance measures of VC-backed firms (Cumming and Li, 2013; Brander et al., 2014). To be sure that rolling mixed syndicates into PVC-backing category does not bias our conclusions we checked the structure of the syndicated deals in our sample (see also Table 3). There are 82 syndicated first round investments. 69 syndicates are classified as PVC-backed deals. Among 69 PVC-backed syndicated deals, 23 are backed by the mix syndicates. This is about $4 \%$ of the total number of deals. We therefore do not expect our results to be affected by our special treatment of this mix case. This intuition was confirmed once we rerun our regression models. We are thankful to the anonymous referee for pointing out this issue.
} 
on the probability of securing VC financing (Gompers, 1996; Gompers and Lerner, 1998; Lerner, 2002a). To proxy for the overall supply of venture capital, we include the log of the amount of funds raised (Fundraising). The demand is approximated by the log of the amount of venture capital and growth capital invested (Investments). Next, we control for the heat of the IPO market and general exit opportunities with the logs of exit proceeds from trade sales (TS exits), and from IPOs (IPO exits). All these variables are defined on a per-portfolio company basis in the year before the VC round takes place. Finally, injection year dummies and a high-tech sector dummy are included in the propensity score model.

\subsection{Descriptive statistics}

We start with the BS, the summary statistics of which are reported in Table 2. For convenience, we first discuss the inputs and outputs and then the regression-related variables. All inputs, link and output variables of the VC-backed firms show increasing patterns. For convenience, we also report the yearly percentage changes of the time-varying variables. Average net fixed assets grow from about $€ 1448 \mathrm{k}$ (median of $€ 236 \mathrm{k}$ ) to $€ 2755 \mathrm{k}$ (median of $€ 505 \mathrm{k}$ ) three years after the transaction. Similarly, we find that all VC-backed companies show steady growth in the average (from 9 to 17) and median (from 2 to 5 ) number of employees between the pre-transaction and the second posttransaction year. The same patterns are observed for the link variable showing the steady increases in shareholder capital on average (from about $€ 1326 \mathrm{k}$ to $€ 3453 \mathrm{k}$ ), and on median (from about $€ 245 \mathrm{k}$ to $€ 679 \mathrm{k})$. Finally, VC-backed firms demonstrate the increasing value added patterns from $€ 327 \mathrm{k}$ to $€ 875 \mathrm{k}$ (average), and from $€ 56 \mathrm{k}$ to $€ 260 \mathrm{k}$ (median) three years after the transaction.

\section{Table 2 HERE}

Table 2 also tabulates the PVC- and GVC-backed firms. It appears that GVC funds back roughly half (47\%) of the VC-backed firms in Belgium (243 firms out of 515). In terms of fixed assets, PVC-backed firms are slightly smaller on average before the VC injection. They overtake GVC-backed companies by a low margin in the second year. Median-wise, PVC-backed firms are 
significantly (as suggested by the non-parametric Mann-Whitney tests) smaller than their GVCbacked peers. PVC-backed firms are larger in terms of the headcount and seem to create more jobs on average over time. In terms of the output, we find both PVC- and GVC-backed firms standing on equal ground on average in the pre-transaction year (future GVC-backed firms produce slightly more value added). Both types of firms display a steady growth in the value added variable on average and on median. However, the output growth considerably accelerates in PVC-backed firms in the second year after the transaction. Firms backed by private investors are also younger (average age is 1.81 vs. 2.27), less profitable (average ROA is -0.38 vs. -0.17), and less levered (average debt-to-total assets is 0.13 vs. 0.26 ).

There are very few statistically significant differences in averages between both types of firms. We observe, however, statistically significant differences in the medians of almost all variables except for the number of employees.

Panel B of Table 2 reveals interesting information about the geographical distribution of the VC investment flow. Although the global picture is quite balanced (193 investments in Flanders region vs. 247 in Walloon region), the $\mathrm{PVC} / \mathrm{GVC}$ tabulations show that the vast majority of the PVC flows to Flanders region (63\%) while Walloon region leads in terms of the GVC (82\%). It confirms the substantial regional heterogeneity in the Belgian venture capital industry.

The summary of the deal-related variables is reported in Table 3. Consistently with the staging and syndication literature, PVC investors syndicate more often ( $13 \%$ vs. only $3 \%$ of the total of 515 firms) and engage in more financing rounds (1.24 vs 1.03) with their portfolio firms (Gompers, 1995, 1996; Davila and Foster, 2003; Cumming and MacIntosh, 2007). It appears that the most active GVC investor is the INVESTS with 196 first round financings. This represents about 38\% of the total number of 515 investments in Belgium over the period 1998-2004 and accounts for more than $75 \%$ of GVC-financed companies.

\section{Table 3 HERE}

The description of the sample created using the propensity score matching procedure is reported in Table 4. The combined sample (CS) displays the growth in all productivity-related variables. 
NVC-backed companies show slowly growing or quite stable levels of the fixed assets, and of the headcount. In VC-backed firms these variables grow quite dramatically. At the same time, both types of firms increase their shareholders' capital and output levels between the pre-transaction and the third post-transaction years Pre-transaction VC-backed firms appear to be on average slightly younger (2 vs. 5.32 years old). Their return on assets is also much lower in comparison to their peers (-0.28 vs. -0.22$)$. Finally, untreated firms show more aggressive financing policies, with an average debt-to-total asset ratio of 3.45 against 0.19 in the VC-backed firms.

\section{Table 4 HERE}

The differences in the growth and in the levels of inputs, output, and link measures may affect the efficiency estimations through the returns-to-scale (RTS) assumptions, discussed in Banker et al. (1984). The developments in DEA methodology have suggested one non-parametric and two parametric tests of the RTS assumptions (Banker, 1993, 1996; Banker et al., 2010). Although not tabulated here, we have implemented all three of these tests. The results clearly rejected the null of the constant RTS assumption (CRS) in favor of the variable one (VRS). In what follows, we report the results of the VRS specifications only. Finally, we have analyzed Pearson correlation matrices for the BS and CS and found no indication of the potential multicollinearity problems.

\section{Results}

\subsection{Efficiency estimations}

Table 5 reports the results of efficiency estimations. In Panels A and B we report the averages of the overall efficiency scores and their decomposition into three term efficiencies. Panel C reports the brief summary of the three DEA specific difference tests for the categories of our interest(Banker, 1993; Banker et al., 2010). For brevity, we aggregate the results of the tests by computing the average number of significance stars. For example, if results of three tests suggest that a difference is significant at $1 \%, 5 \%$, and $10 \%$ respectively $(* * *, * *, *)$, we report this difference to be roughly significant at $5 \%(* *)$. 
Panel A highlights the results for the sample of 515 VC-backed firms. The average efficiency level of VC-backed firms over the four-year study window is about $0.56(56 \%)$. Term structure reveals that overall efficiency increases over the $T-1$ to $T+3$ period by about $6.4 \%$. The pattern of these improvements seems to be volatile and somewhat concave (also shown in Figure 1(a)). The tabulation of the GVC- and PVC-backed firms indicates that overall, the latter are more efficient than the former by about $10 \%$. This difference is statistically significant at aggregate $1 \%$ level. In both cases we observe increases in efficiency following the transaction year. PVC-backed firms show higher pre-transaction efficiency levels, and demonstrate higher gains of efficiency over the period $T-1$ to $T$. These results indicate that PVC firms might choose potentially more efficient firms within the pool of candidates for VC financing. At the same time, the difference between PVCand GVC-backed firms in this period is only marginally significant at aggregate $10 \%$ level. Both types of portfolio companies lose in productivity in the second post-transaction year. The slight efficiency growth resumes in the PVC-backed firms afterwards while GVC-backed firms continue to lose in productivity. In each post-transaction period, the difference in productivity in PVCand GVC-backed firms is significant at aggregate $1 \%$ level.

\section{Table 5 and Figure 1 HERE}

Panel B and Figure 1(b) report the results of efficiency measurements using the combined sample (CS). Global efficiency in the SMEs is about 47\%. VC-backed firms lag $7 \%$ behind the average, and $13 \%$ behind their NVC-backed peers in terms of overall productivity over the estimation of window. The difference between VC- and NVC-backed firms seems to be only marginally significant at aggregate 10\% level (see Panel C). Consistent with our previous results, the difference in the overall productivity of PVC- and GVC-funded firms is significant at aggregate $1 \%$ level. In the combined sample we find no differences in the pre-transaction efficiency levels between these two categories. In each post-transaction year, however, the differences are statistically significant at $5 \%$ or $1 \%$ levels. The "underperformance" of VC seems to be caused by GVC. The difference in the productivity of GVC- and NVC-backed firms is significant at aggregate $5 \%$ level overall. PVC-backed firms have almost 50\% (0.496) efficiency levels and this is $2 \%$ above the average pro- 
ductivity score of comparable firms. Interestingly, this difference is not significant (neither are the differences in the term efficiencies) suggesting no effect of PVC funding.

Both panels A \& B suggest that INVESTS funds are the culprits of this subpar "performance".

They seem to choose the least efficient firms and drag down GVC estimates in the post transaction years. This may suggest that our results are driven by this investor. We note however that INVESTS is a category that regroups a set of various GVC funds that operate independently, and that INVESTS are involved in roughly $80 \%$ of GVC-backed deals in our sample. We are therefore effectively talking about the major bulk of GVC flow. Moreover, in a series of unreported (but available upon request) tests we verify that INVESTS-backing significantly differs from that by PVC, SRIW, and NVC pre- and post-transaction. At the same time, we found no difference in efficiency of firms backed by INVESTS in comparison to those funded by other GVC investors.

Overall, the evidence is supportive of our main hypothesis. Entrepreneurial firms backed by PVC seem to show greater efficiency levels and improvements in comparison to their GVC-backed counterparts. Although these results are quite comforting, the casual link between the investor type and efficiency is still an open question. To understand this link, we move to multivariate regression analyses presented in the following section.

\subsection{Type of investor and its implications on efficiency}

Table 6 reports the regressions estimated using the base sample of 515 VC-backed firms. Column (0) provides the results for the zero-model in which only control variables are used. Models (1) to (5) test the impact of a respective investor type on the overall efficiency over the study period. The $R^{2}$ is computed following Papke and Wooldridge (1996) and Ramalho et al. (2010) as a squared correlation between the observed and predicted values of the response. As before, we report GIMV estimations for the sake of comparison.

Model (1) suggests that the presence of private investor in the first financing round has a positive and statistically significant (1\%) effect on the future efficiency of a portfolio firm. The corresponding average partial effect (0.099) implies that the arrival of the PVC investor in the 
equity of the firm improves productivity by almost 10\% (on average) over the three years posttransaction. Models (2) to (5) show the results of the similar estimations disentangling the effects of different public investors. Model (6) combines all specific public investors and GIMV. As could be expected, GIMV has a statistically significant effect on the productivity of its targets. The gain in productivity could go as high as $19 \%$ (Model (3)), although in the combined model the effect is at a $15 \%$ level (Model (6)). Conversely, being backed by one of the INVEST funds leads to statistically significant destruction of productivity by almost $13 \%$. All regression tests (see the p-values) reject the errors in the specifications or functional forms.

\section{Table 6 HERE}

Table 7 reports the estimations for the combined sample. In accordance with our univariate analysis of efficiency, Model (1) reports that in general the presence of a VC investor in the equity of the firm has a negative and significant (5\%) impact on the subsequent productivity of portfolio firms. The economic size of the average partial effect implies a loss of productivity of about $4.2 \%$ over the study period. The split between different investor types suggests that being financed by a PVC investor (Model (2)) has a positive but rather weak (10\%) effect. On average, PVC-backed firms see their overall efficiency improve by about 3.2\%. Models (4) and (5) suggest that GIMV backing has a statistical (at the $5 \%$ level) and positive economic (12.2\%) effect on the dynamic productivity while INVESTS-sponsored companies lose about $11.8 \%$ on average in efficiency over the study period. This latter effect is statistically significant at $1 \%$ and is also confirmed in Model (7). Again, the regression tests suggest no errors in the specifications or functional forms of the models.

\section{Table 7 HERE}

Overall these findings are again supportive of the hypothesis discussed in Section 2 although the combined sample shows that the presence of PVC investors has a very limited effect on the post-transaction efficiency. As the efficiency scores can be decomposed into term efficiencies, it is also possible to investigate whether the VC investor type effect persists across time. To answer 
this question we run separate unreported regressions of the term efficiency scores on the variables of interest and controls. The results were consistent with our main story.

\subsection{Selection and endogeneity issues}

There may still be some issues related to the endogenous nature of VC funding. To be specific, there may be two distinct sorts of biases that apply to BS and CS respectively.

First, there may be a selection problem in which GVC funds target firms that are systematically different along some unobservable characteristics from those financed by PVC funds. If for example PVC funds cherry-pick firms with greater growth prospects ex ante, our statement about the benefit of PVC ex post is misleading. The same issue would be expected if GVC funds target firms that are systematically overlooked by PVC funds. To alleviate this concern, we follow (Chemmanur et al., 2011; Croce et al., 2013) and use treatment effect models to control for the effect of the unobservables. The results are reported in Table 8. The dependent variable for the probit selection equation is the PVC-backing. Its specification is similar to the one we used for the propensity score matching (see Section 3). There are two slight differences because of the relatively small size of the base sample. First, proceeds from IPO exits and trade sale exits were rolled into one "Exits" variable. Second, injection year dummies were replaced by the "2000s Dummy" to control for the bubble years. The outcome equations have the same specification as in the previously reported models for the base sample. Note that DEA score is a proportion falling into [0;1] interval. It should therefore be transformed before it is plugged as the dependent variable in the OLS outcome equation. We use the arcsin-square-root transform because the usual log-odds transform is infeasible in the presence of bound values. All regressions were estimated with robust standard errors. Due to the space limitations, only the brief results are reported.

Panel A shows the answer to the question of "what if" PVC-backed firms were GVC-backed and vice versa? The efficiency of GVC-backed firms would have been about $16 \%$ higher if they had received financing from private VC fund. Similarly, PVC-backed firms would have lost about 7\% in efficiency if they had been financed by GVC. Both parametric and non-parametric tests suggest 
these results are statistically significant at $1 \%$ level.

\section{Table 8 HERE}

Second, there may be an endogeneity problem in our analysis of VC- vs. NVC-backed firms. This is again related to the potentially different "profile" of firms that secure VC financing compared to the NVC-backed firms. These ex ante differences may be correlated with ex post performance of the targets. The problem is that we observe these "profiles" only partially. Observable differences between treated and control firms are ruled out by the matching procedure (Chemmanur et al., 2011). However, heterogeneity along the unobservables could still be an issue. To alleviate this concern, we employ the similar switching regression methodology except that we have to go back to the entire population of Belgian SMEs. In this context we look at the distinctions between the PVC vs. NVC backing, and between the GVC vs. NVC backing. Our first stage regressions are two probit models of the same specification and on the same population as we used in the propensity score matching procedure. The dependent variable is either PVC- or GVC-backing. Corresponding inverse Mills ratios (IMR) are computed for all companies in the population. In the second stage we use the NVC-backed firms returned from the matched procedure. This is because it is computationally infeasible to estimate efficiency of over 150k firms (the population size). Since IMRs are computed using the entire population, the use of the reduced samples in the second stage should not be problematic. Second stage regressions are estimated via OLS with robust standard errors and have the same specifications as the models reported previously for the combined sample.

The summarized results are reported in Panel B. Productivity of control firms would have experienced no change if they had been funded by PVC. NVC-backed firms would have shown a drop in productivity of $10 \%$ (significant at $1 \%$ both in parametric and non-parametric tests) if they had secured GVC funding. If PVC-backed firms had not been financed by any sort of VC, their productivity might have been better, but the difference is not significant. Finally, it appears that if GVC-backed firms had received no funding they would have gained about $7.5 \%$ in productivity. Again, this improvement is statistically significant at $1 \%$ level both in parametric and 
non-parametric tests. Overall, controlling for the potential unobservable heterogeneity between the VC-backed and matched firms, our previous results seem to be confirmed.

Overall, controlling for the potential unobservable heterogeneity between the VC-backed and matched firms, our previous results seem to be confirmed.

\subsection{Comparison with the total factor productivity approach}

Previous research used the total factor productivity (TFP) measure of efficiency in the VC context (Chemmanur et al., 2011; Croce et al., 2013). It is therefore insightful to see whether our results hold against alternative estimation methods.

Even though this is a useful check in order to relate this study to the existing literature, implementing the TFP approach raises a number of issues. To measure the TFP properly, we need to estimate the regression of the natural log of output on the natural logs of inputs. The output is sales revenues, while the usual inputs are labor and capital. Although we have data on the inputs, we lack data on the output measure in this context. As we mentioned elsewhere, in Belgium disclosure of sales revenues is subject to a managerial decision. Thus, our first issue is that we do not have the complete data on sales in our sample. To estimate the TFP we rely on the SYS-GMM procedure described in Blundell and Bond (2000). Following Chemmanur et al. (2011) and Croce et al. (2013) we perform a by-industry estimation of the TFP. This gives rise to a second issue, since we have to partition the base or combined samples (with already limited number of firms) into industry subsets. This leads to a further reduction of the sample size for the TFP estimations. We nevertheless use these reduced samples to estimate the TFP. The results, available upon request, are materially similar to our main findings and do not change the conclusions of the study.

\section{Conclusion}

In this study we analyze the implications of $\mathrm{VC}$ financing on the productivity of the entrepreneurial firms. Our context is the Belgian venture capital industry. We focus on the relationship between the 
type of financial backer - government or private - and the productivity of its targets. This question is addressed using a unique hand-collected database of Belgian VC-backed firms during the period 1998-2007. We use Dynamic Data Envelopment Analysis methodology to estimate efficiency levels and changes between the first pre-transaction year $(T-1)$ and three years following the injection of venture capital $(T+3)$.

Overall the results are suggestive of the following. Within the pool of Belgian VC-backed firms, being financed by PVC investors significantly improves efficiency of portfolio companies. Being financed by a GVC fund, and in particular by the sub-regional investment companies (the "INVESTS"), implies a significant reduction in productivity. SRIW and GIMV have respectively a very limited negative and highly positive influence on the post-transaction changes in productivity in their targets. Factoring in comparable NVC-backed firms suggests that VC-backing in general destroys productivity in Belgium. This, however, comes almost exclusively from the GVC backing, especially from the INVESTS. Comparing PVC to NVC backing suggests statistically weak-to-no effect of private $\mathrm{VC}$ on productivity.

Our explicit analysis of the investors' typology on productivity contributes to the ongoing debates on the effects of GVC (Cumming and Li, 2013; Brander et al., 2014), and on the effects of VC on productivity (Chemmanur et al., 2011; Croce et al., 2013). Instead of focusing on output measures alone to assess the incremental impact of VC backing on a firm's success, we dig into the causality of this output, namely the efficiency of the production process. We are able to distinguish between financial support and value added provided by GVC and PVC investors and underline the impact of this distinction on the target's efficiency. This result is important as the latter itself is one of the fundamental drivers of firm's performance (Bottazzi et al., 2008a).

At the same time, we are aware about several important limitations of our study. Our dataset does not contain crucial fund-related characteristics, such as the age and/or the size of the fund, the number of portfolio companies per fund manager to name but a few. In addition, we do not have any information on the valuations or shareholding stakes in the deals. This, however, would add a lot to our understanding of the effect of the VC financier type on the efficiency of its targets. Another limitation is due to the period under study: the INVESTS have been thoroughly 
reorganized under the cupola of the Sowalfin, and the governance of this myriad of sub-regional funds has been subsequently revised since then. Thus, the results of our study must be preferably interpreted as a comparative approach of different types of $\mathrm{VC}$ organizations for a homogenous time period, rather than as a contemporaneous and reliable picture of the VC industry prevailing in Belgium at the current time. ${ }^{8}$

In spite of the aforementioned limitations, our results are insightful for academic research. Analyzing the effects of GVC programs is a challenging task. Therefore, it is beneficial to assess this question in many different ways. Considerable attention is paid to the implications of VC financing on business creation, growth, innovation, regional development and employment. Our results investigate yet another aspect of the firm's performance and favor the conjecture that, in the case of VC, efficiency is also contingent on the financier's profile. Our results are also important for entrepreneurs and for the industry. For small firms, venture capitalists provide more than just money but also advice and networks. The quality of the latter is contingent on the identity of the investor. Considering this, entrepreneurs should be aware of the implications of this investor heterogeneity on their firms' performance before paying the price. Ultimately, our results are potentially useful for Belgian policy makers. Although we do not conclude that their funds are harmful for the economy, our evidence suggests that GVC funds' investments are not helping productivity within their targets. This may imply an inefficient use of the taxpayers' money, which is why a reassessment (and possibly in-depth restructuring) of these programs might be warranted.

\footnotetext{
${ }^{8}$ Our supplementary analyses showed that this reorganization had no effect on our conclusions. The results are available upon request.
} 


\section{Acknowledgments}

This research benefited from the support of the Belgian "Fonds de la Recherche Fondamentale Collective" (FRFC). We are grateful to Fabio Bertoni, Douglas Cumming, David Devigne, Philipp Geiler, Alexander Peter Groh, Sophie Manigart, William L. Megginson, Pierre-Armand Michel, Bartolome Pascual-Fuster, Andrea Schertler, Armin Schwienbacher, Bernard Surlemont, Marc Umber, Charles Van Wymeersch, Uwe Walz, Mike Wright, and the participants of the MFS 2010 Annual Conference (Barcelona, Spain), the BENELUX Corporate Finance Day 2010 (Groningen, The Netherlands), the VICO final conference 2011 (Stresa, Italy), the 30th International AFFI conference 2013 (Lyon, France), and the 11th Corporate Finance Day 2013 (Liège, Belgium) for their useful comments and remarks on earlier versions of this paper. We are also grateful to Joaquim J.S. Ramalho for sharing the technical details related to the methodological part of this paper. Georges Hübner thanks Deloitte Belgium and Deloitte Luxembourg for their financial support. Finally, we thank three anonymous referees and the editor for their comments and suggestions. All remaining errors are ours.

\section{References}

Alperovych, Y., Amess, K., and Wright, M. (2013). Private equity firm experience and buyout vendor source: What is their impact on efficiency? European Journal of Operational Research, 228(3):601-611.

Alperovych, Y. and Hübner, G. (2013). Incremental impact of venture capital financing. Small Business Economics, 41(3):651-666.

Amess, K. (2003). The effect of management buyouts on firm-level technical efficiency: evidence from a panel of UK machinery and equipment manufacturers. Journal of Industrial Economics, 51(1):35-44.

Banker, R., Charnes, A., and Cooper, W. (1984). Some models for estimating technical and scale inefficiencies in data envelopment analysis. Management Science, 30(9):1078-1092.

Banker, R. D. (1993). Maximum likelihood, consistency and data envelopment analysis: a statistical foundation. Management Science, 39(10):1265-1273.

Banker, R. D. (1996). Hypothesis tests using data envelopment analysis. Journal of Productivity Analysis, 7:139-159.

Banker, R. D., Zheng, Z. E., and Natarajan, R. (2010). DEA-based hypothesis tests for comparing two groups of decision making units. European Journal of Operational Research, 206(1):231-238.

Barber, B. M. and Lyon, J. D. (1996). Detecting abnormal operating performance: the empirical power and specification of test statistics. Journal of Financial Economics, 41:359-399. 
Bascha, A. and Walz, U. (2006). Financing practices in the German venture capital industry: an empirical assessment, chapter 15, pages 217-248. Elsevier Press.

Bayenet, B. (1996). Les invests wallons. Courrier hebdomadaire, n.1540-1541, p.54. Centre de recherche et d'information socio-politique (CRiSP).

Blundell, R. and Bond, S. (2000). GMM estimation with persistent panel data: an application to production functions. Econometric reviews, 19(3):321-340.

Bottazzi, G., Secchi, A., and Tamagni, F. (2008a). Productivity, profitability and financial performance. Industrial and Corporate Change, 17(4):711-751.

Bottazzi, L., da Rin, M., and Hellmann, T. (2008b). Who are the active investors? Evidence from venture capital. Journal of Financial Economics, 89:488-512.

Brander, J., Du, Q., and Hellmann, T. (2014). The effects of government-sponsored venture capital: International evidence. Review of Finance, forthcoming.

Brander, J. A., Amit, R., and Antweiler, W. (2002). Venture-capital syndication: improved venture selection vs. the value-added hypothesis. Journal of Economics and Management Strategy, 11(3):423-452.

Chanine, S., Filatotchev, I., and Wright, M. (2007). Venture capitalists, business angels, and performance of entrepreneurial IPOs in the UK and France. Journal of Business Finance and Accounting, 34(3/4):505-528.

Charnes, A., Cooper, W., and Rhodes, E. (1978). Measuring the efficiency of decision making units. European Journal of Operational Research, 2:429-444.

Chemmanur, T. J., Krishnan, K., and Nandy, D. K. (2011). How does venture capital financing improve efficiency in private firms? a look beneath the surface. Review of Financial Studies, 24(12):4037-4090.

Chen, C.-M. and van Dalen, J. (2010). Measuring dynamic efficiency: theories and integrated methodology. European Journal of Operational Research, 203:749-760.

Cochrane, J. H. (2005). The risk and return of venture capital. Journal of Financial Economics, 75:3-52.

Cook, W. D. and Seiford, L. M. (2009). Data envelopment analysis - thirty years on. European Journal of Operational Research, 192:1-17.

Cooper, W. W., Seiford, L. M., and Tone, K. (2007). Data Envelopment Analysis: A Comprehensive Text with Models, Applications, References and DEA-Solver Software. Springer Science and Business Media, LLC, 2nd. edition.

Cornelli, F. and Yosha, O. (2003). Stage financing and the role of convertible securities. Review of Economic Studies, 70:1-32.

Croce, A., Martí, J., and Murtinu, S. (2013). The impact of venture capital on the productivity growth of european entrepreneurial firms: 'screening' or 'value added' effect? Journal of Business Venturing, 28:489-510.

Cumming, D. (2003). The structure, governance and performance of UK venture capital trusts. Journal of Corporate Law Studies, 3(2):191-217.

Cumming, D. (2007). Government policy towards entrepreneurial finance: innovation investment funds. Journal of Business Venturing, 22:193-235.

Cumming, D. and Johan, S. (2009). Pre-seed government venture capital funds. Journal of International Entrepreneurship, 7:26-56.

Cumming, D. and Li, D. (2013). Public policy, entrepreneurship, and venture capital in the United States. Journal of Corporate Finance, 23:345-367. 
Cumming, D. J., Grilli, L., and Murtinu, S. (2013). Governmental and independent venture capital investments in Europe: a firm-level performance analysis. Working paper.

Cumming, D. J. and MacIntosh, J. G. (2003). Comparative venture capital governance: private versus labour soponsored venture capital funds. CESifo working paper No. 853.

Cumming, D. J. and MacIntosh, J. G. (2006). Crowding out private equity: Canadian evidence. Journal of Business Venturing, 21:569-609.

Cumming, D. J. and MacIntosh, J. G. (2007). Mutual funds that invest in private equity? an analysis of laboursponsored investment funds. Cambridge Journal of Economics, 31:445-487.

Davila, A. and Foster, G. (2003). Staging venture capital: empirical evidence on the differential roles of early versus late rounds. Working paper.

Davila, A., Foster, G., and Gupta, M. (2003). Venture capital financing and the growth of startup firms. Journal of Business Venturing, 18:689-708.

de Clercq, D. and Manigart, S. (2007). The venture capital post-investment phase: opening the black box of involvement, in "Handbook of research on venture capital", chapter 7, pages 193-218. Edward Elgar Publishing Inc.

Debreu, G. (1959). Theory of value: an axiomatic analysis of economic equilibrium. Yale University Press.

Dehejia, R. H. and Wahba, S. (2002). Propensity score-matching methods for nonexperimental causal studies. Review of Economics and Statistics, 84(1):151-161.

Diamond, A. and Sekhon, J. S. (2012). Genetic matching for estimating casual effects: a general multivariate matching method for achieving balance in observational studies. Review of Economics and Statistics, forthcoming.

EVCA (1998-2007). EVCA yearbooks 1998-2007. European private equity and venture capital association.

Färe, R. and Grosskopf, S. (1996). Intertemporal Production Frontiers: with Dynamic DEA. Springer, 1 edition.

Farrell, M. (1957). The measurement of productive efficiency. Journal of the Royal Statistical Society, 120(3):253290.

Florin, J. (2005). Is venture capital worth it? Effects on firm performance and founder returns. Journal of Business Venturing, 20:113-135.

Gompers, P. (1995). Optimal investment, monitoring, and the staging of venture capital. Journal of Finance, 50:1461-1490.

Gompers, P. (1996). Grandstanding in the venture capital industry. Journal of Financial Economics, 42:133-156.

Gompers, P. and Lerner, J. (1996). The use of convenants: an empirical analysis of venture partnership agreements. Journal of Law and Economics, 39(2):463-498.

Gompers, P. and Lerner, J. (1998). What drives venture capital fundraising? Working paper.

Gompers, P. and Lerner, J. (1999). An analysis of compensation in the U.S. venture capital partnership. Journal of Financial Economics, 51:3-44.

Gompers, P. and Lerner, J. (2000). Money chasing deals? The impact of fund inflows on private equity valuations. Journal of Financial Economics, 55:281-325.

Gompers, P. and Lerner, J. (2004). Venture Capital Cycle. The MIT Press, Cambridge, Massachusetts, London, England, 2 edition. 
Gregoriou, G. N., Sedzro, K., and Zhu, J. (2005). Hedge fund performance appraisal using data envelopment analysis. European Journal of Operational Research, 164:555-571.

Hand, J. R. (2007). Determinants of the round-to-round returns to pre-IPO venture capital investments in U.S. biotechnology companies. Journal of Business Venturing, 22:1-28.

Harris, R., Siegel, D. S., and Wright, M. (2005). Assessing the impact of management buyouts on economic efficiency: plant-level evidence from the United Kingdom. Review of Economics and Statistics, 87(1):148-153.

Heger, D., Fier, A., and Murray, G. (2005). Review essay: regional venture capital policy: UK and Germany compared. Venture Capital, 7(4):373-383.

Hellmann, T. (1998). The allocation of control rights in venture capital contracts. RAND Journal of Economics, 29(1):57-76.

Hellmann, T. (2006). IPOs, acquisitions, and the use of convertible securities in venture capital. Journal of Financial Economics, 81:649-679.

Hellmann, T. and Puri, M. (2000). The interaction between product market and financing strategy: the role of venture capital. Review of Financial Studies, 13(4):959-984.

Hellmann, T. and Puri, M. (2002). Venture capital and the professionalization of start-up firms: empirical evidence. Journal of Finance, 57(1):169-197.

Hochberg, Y. V., Ljungqvist, A., and Lu, Y. (2007). Whom you know matters: venture capital networks and investment performance. Journal of Finance, 62(1):251-301.

Hsu, D. H. (2000). Do venture capitalists affect commercialization strategies at start-ups? Working paper.

Hsu, D. H. (2004). What do entrepreneurs pay for venture capital affiliation? Journal of Finance, 59(4):1805-1844.

Jensen, M. C. (1986). Agency costs of free cash flow, corporate finance and takeovers. American Economic Review, $76(2): 323-329$.

Jovanovic, B. (1982). Selection and evolution of the industry. Econometrica, 50(3):649-670.

Keuschnigg, C. and Nielsen, S. B. (2001). Public policy for venture capital. International Tax and Public Finance, 8:557-572.

Knockaert, M., Lockett, A., Clarysse, B., and Wright, M. (2006). Do human capital and fund characteristics drive follow-up behaviour of early stage high-tech VCs? International Journal of Technology Management, $34(1 / 2): 7-27$.

Korteweg, A. and Sørensen, M. (2010). Risk and return characteristics of venture capital-backed entrepreneurial companies. Review of Financial Studies, 23(10):3738-3772.

Kortum, S. and Lerner, J. (2000). Assessing the contribution of venture capital to innovation. RAND Journal of Economics, 31(4):674-692.

Leleux, B. and Surlemont, B. (2003). Public versus private venture capital: seeding or crowding out? A panEuropean analysis. Journal of Business Venturing, 18:81-104.

Lerner, J. (1994). The syndication of venture capital investments. Financial Management, 23(3):16-27.

Lerner, J. (1995). Venture capital and the oversight of private firms. Journal of Finance, 50(1):301-318.

Lerner, J. (1999). The government as venture capitalist: the long-run impact of the SBIR program. Journal of Business, 72(3):285-318. 
Lerner, J. (2002a). Boom and bust in the venture capital industry and the impact on innovation. Federal Reserve Bank of Atlanta Economic Review, 4:25-39.

Lerner, J. (2002b). When bureaucrats meet entrepreneurs: The design of effective 'public venture capital' programmes. Economic Journal, 112(477):F73-F84.

Lerner, J. (2009). Boulevard of Broken Dreams: Why Public Efforts to Boost Entrepreneurship and Venture Capital Have Failed - and What to Do about It. The Kaufman Foundatin series on innovation and entrepreneurship. Princeton University Press, Princeton and Oxford.

Lerner, J. (2010). The future of public efforts to boost entrepreneurship and venture capital. Small Business Economics, 35:255-264.

Lerner, J., Schoar, A., and Wongsunwai, W. (2007). Smart institutions, foolish choices: the limited partner performance puzzle. Journal of Finance, 62(2):731-764.

Lerner, J. and Watson, B. (2008). The public venture capital challenge: the Australian case. Venture Capital, 10(1):1-20.

Lichtenberg, F. R. and Siegel, D. (1990). The effects of leveraged buyouts on productivity and related aspects of firm behavior. Journal of Financial Economics, 27:165-194.

Lockett, A. and Wright, M. (2001). The syndication of venture capital investments. OMEGA The International Journal of Management Science, 29:375-390.

Macmillan, I. C., Siegel, R., and Subbanarasimha, P. N. (1985). Criteria used by venture capitalists to evaluate new venture proposals. Journal of Business Venturing, 1(1):119-128.

Macmillan, I. C., Zemann, L., and Subbanarasimha, P. (1987). Criteria distinguishing successful from unsuccessful ventures in the venture screening process. Journal of Business Venturing, 2(2):123-137.

Manigart, S., Baeyens, K., and Hyfte, W. V. (2002). The survival of venture capital backed companies. Venture Capital, 4(2):103-124.

Maula, M., Murray, G., and Jääskeläinen, M. (2007). Public financing of young innovative companies in Finland. Technical report, MTI Publications.

Metrick, A. and Yasuda, A. (2010). The economics of private equity funds. Review of Financial Studies, 23(6):23032341.

Murteira, J. M. R. and Ramalho, J. J. S. (2013). Regression analysis of multivariate fractional data. Econometric reviews, forthcoming.

Papke, L. E. and Wooldridge, J. M. (1996). Econometric methods for fractional response variables with an application to 401(k) plan participation rates. Journal of Applied econometrics, 11:619-632.

Puri, M. and Zarutskie, R. (2012). On the life-cycle dynamics of venture-capital- and non-venture-capital-fianced firms. Journal of Finance, 67(6):2247-2293.

Ramalho, E. A., J.S.Ramalho, J., and Henriques, P. D. (2010). Fractional regression models for second stage DEA efficiency analyses. Journal of Productivity Analysis, 34:239-255.

Ramalho, E. A., Ramalho, J. J., and Murteira, J. M. (2011). Alternative estimating and testing empirical strategies for fractional regression models. Journal of Economic Surveys, 25(1):19-68.

Ramalho, E. A., Ramalho, J. J., and Murteira, J. M. (2013). A generalized goodness-of-functional form test for binary and fractional resgression models. The Manchester School, forthcoming. 
Rin, M. D., Nicodano, G., and Sembenelli, A. (2006). Public policy and the creation of active venture cpaital markets. Journal of Pubilc Economics, 90:1699-1723.

Rosenbaum, P. R. and Rubin, D. B. (1985). Constructing a control group using multivariate matched sampling methods that incorporate the propensity score. The American Statistician, 39(1):33-38.

Samila, S. and Sorenson, O. (2011). Venture capital, entrepreneurship and economic growth. Review of Economics and Statistics, 93(1):338-349.

Sapienza, H. J. (1992). When do venture capitalists add value? Journal of Business Venturing, 7(1):9-27.

Sapienza, H. J., Amason, A. C., and Manigart, S. (1994). The level and nature of venture capitalist involvement in their portfolio companies. Managerial Finance, 20(1):3-17.

Sapienza, H. J., Manigart, S., and Vermeir, W. (1996). Venture capitalist governance and value added in four countries. Journal of Business Venturing, 11:439-469.

Shane, S. (2009). Why encouraging more people to become entrepreneurs is bad public policy. Small Business Economics, 33:141-149.

Sørensen, M. (2007). How smart is smart money? A two-sided matching model of venture capital. Journal of Finance, 62(6):2725-2762.

Sunley, P., Klagge, B., Brendt, C., and Ron, M. (2005). Venture capital programmes in the UK and Germany: in what sense regional policies? Regional Studies, 39(2):255-273.

Tone, K. (2001). A slacks-based measure of efficiency in data envelopment analysis. European Journal of Operational Research, 130:498-509.

Tone, K. and Tsutsui, M. (2010). Dynamic DEA: a slacks-based measure approach. OMEGA The International Journal of Management Science, 38:145-156.

Tyebjee, T. T. and Bruno, A. V. (1984). A model of venture capitalist investment activity. Management Science, 30(9):1051-1066. 


\section{A Tables and figures}

Figure 1: Efficiency evolution over time.

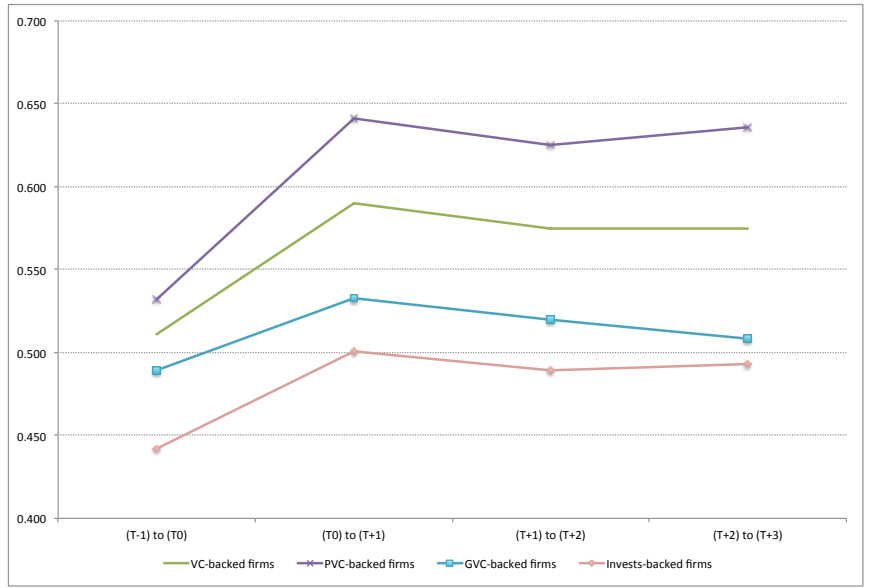

(a) Base sample.

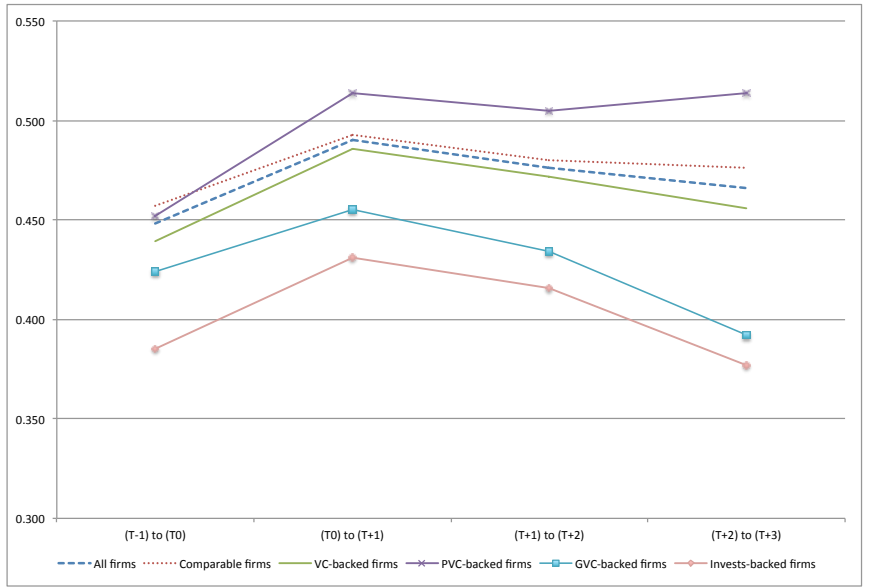

(b) Combined sample.

The graph presents the productivity patterns of Belgian VC-backed firms between the first pre- and third post-transaction years. The term productivity scores are estimated using the DDEA methodology. For details see Section 3.

Table 1: Industry and investment patterns of the BS.

\begin{tabular}{|c|c|c|c|c|c|c|}
\hline & \multicolumn{2}{|c|}{ All VC-backed firms } & \multicolumn{2}{|c|}{ PVC-backed firms } & \multicolumn{2}{|c|}{ GVC-backed firms } \\
\hline & $\mathrm{N}$ & $\%$ & $\mathrm{~N}$ & $\%$ & $\mathrm{~N}$ & $\%$ \\
\hline \multicolumn{7}{|c|}{ Panel A: Industry patterns - number of firms per industry. } \\
\hline R \& D (72) & 40 & $8 \%$ & 21 & $8 \%$ & 19 & $8 \%$ \\
\hline Manufacturing (12-33) & 82 & $16 \%$ & 26 & $10 \%$ & 56 & $23 \%$ \\
\hline Construction \& Commodities (35-43) & 34 & $7 \%$ & 6 & $2 \%$ & 28 & $12 \%$ \\
\hline HORECA \& Transport (45-56) & 83 & $16 \%$ & 33 & $12 \%$ & 50 & $21 \%$ \\
\hline IT \& Telecom (58-63) & 110 & $21 \%$ & 84 & $31 \%$ & 26 & $11 \%$ \\
\hline Services $(69-71,>73)$ & 166 & $32 \%$ & 102 & $38 \%$ & 64 & $26 \%$ \\
\hline
\end{tabular}

Panel B: Time patterns - number of firms per year.

$\begin{array}{lrrr}1998 & 65 & 35 & 30 \\ 1999 & 87 & 55 & 32 \\ 2000 & 101 & 69 & 32 \\ 2001 & 71 & 39 & 32 \\ 2002 & 72 & 32 & 40 \\ 2003 & 63 & 19 & 44 \\ 2004 & 56 & 23 & 33\end{array}$

Figures in parentheses are the 2-digit NACE-BEL 2008 codes. 


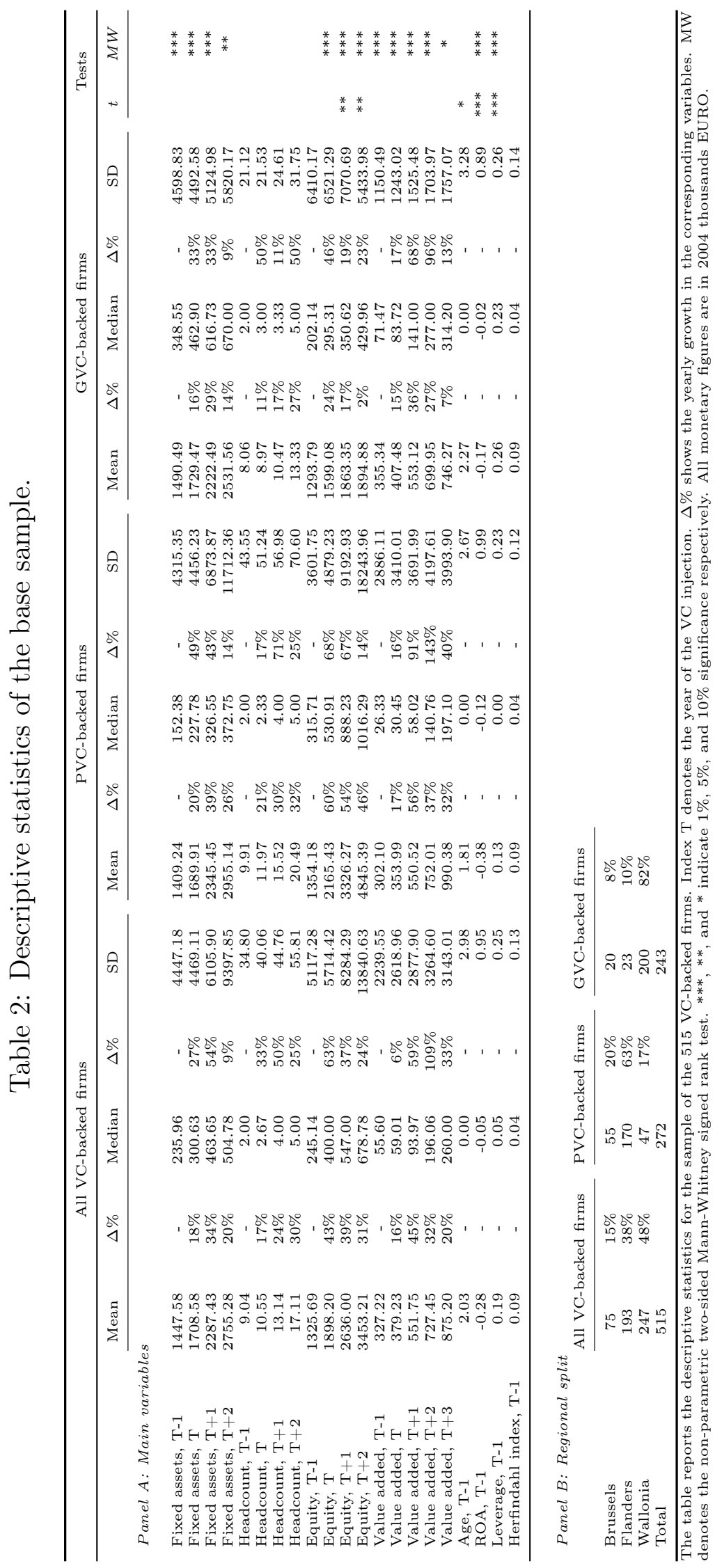


Table 3: Deal-related variables.

\begin{tabular}{|c|c|c|c|c|c|c|}
\hline & $\mathrm{N}$ & $\%$ of $(1)$ & $\mathrm{N}$ & $\%$ of $(1)$ & Mean & $\mathrm{SD}$ \\
\hline \multicolumn{7}{|l|}{ Panel A: General info } \\
\hline & \multicolumn{2}{|c|}{ First round investments } & \multicolumn{2}{|c|}{ Syndication } & \multicolumn{2}{|c|}{ Number of rounds } \\
\hline VC-backed firms (1) & 515 & $100 \%$ & 82 & $16 \%$ & 1.142 & 0.480 \\
\hline PVC-backed firms & 272 & $53 \%$ & 69 & $13 \%$ & 1.239 & 0.618 \\
\hline GVC-backed firms & 243 & $47 \%$ & 13 & $3 \%$ & 1.033 & 0.201 \\
\hline \multicolumn{7}{|c|}{ Panel B: By investment firm } \\
\hline GIMV & 15 & $3 \%$ & & & & \\
\hline SRIW & 41 & $8 \%$ & & & & \\
\hline INVESTS & 196 & $38 \%$ & & & & \\
\hline Oher GVC & 46 & $9 \%$ & & & & \\
\hline
\end{tabular}

Table 8: Treatment effect of private vs. government VC.

\begin{tabular}{|c|c|c|}
\hline \multicolumn{3}{|l|}{ Panel A: BS sample. } \\
\hline Mean efficiency of GVC-backed firms & Potential efficiency if GVC-backed firms were PVC-backed & Difference \\
\hline 0.512 & 0.673 & $0.160^{* * *,+++}$ \\
\hline Mean efficiency of PVC-backed firms & Potential efficiency if PVC-backed firms were GVC-backed & Difference \\
\hline 0.608 & 0.537 & $-0.071^{* * *,+++}$ \\
\hline \multicolumn{3}{|l|}{ Panel B: CS sample. } \\
\hline Mean efficiency of NVC-backed firms & Potential efficiency if NVC-backed firms were: & Difference \\
\hline 0.476 & $\begin{array}{ll}\text { PVC-backed } & 0.476 \\
\text { GVC-backed } & 0.377\end{array}$ & $\begin{array}{l}0.000 \\
-0.100^{* * *,+++}\end{array}$ \\
\hline Mean efficiency of PVC-backed firms & Potential efficiency if PVC-backed firms were NVC-backed & Difference \\
\hline 0.496 & 0.515 & 0.019 \\
\hline Mean efficiency of GVC-backed firms & Potential efficiency if GVC-backed firms were NVC-backed & Difference \\
\hline 0.426 & 0.502 & $0.075^{* * *,+++}$ \\
\hline
\end{tabular}




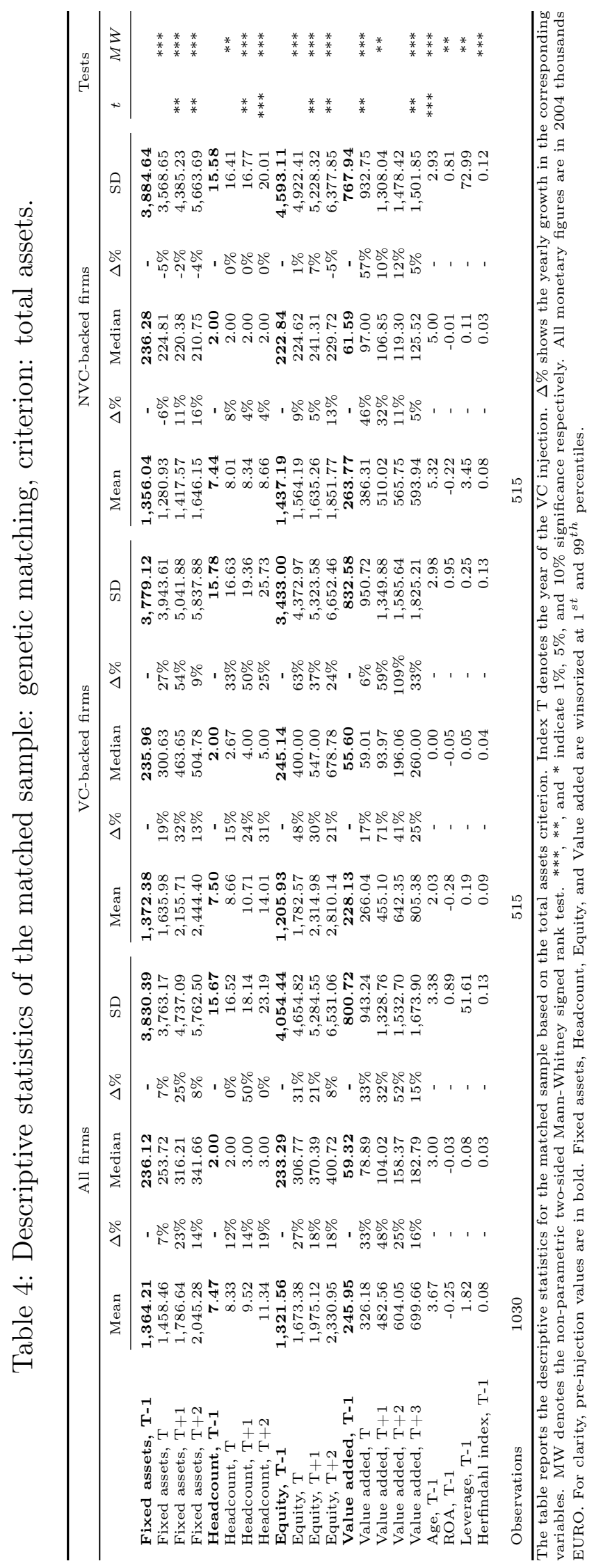




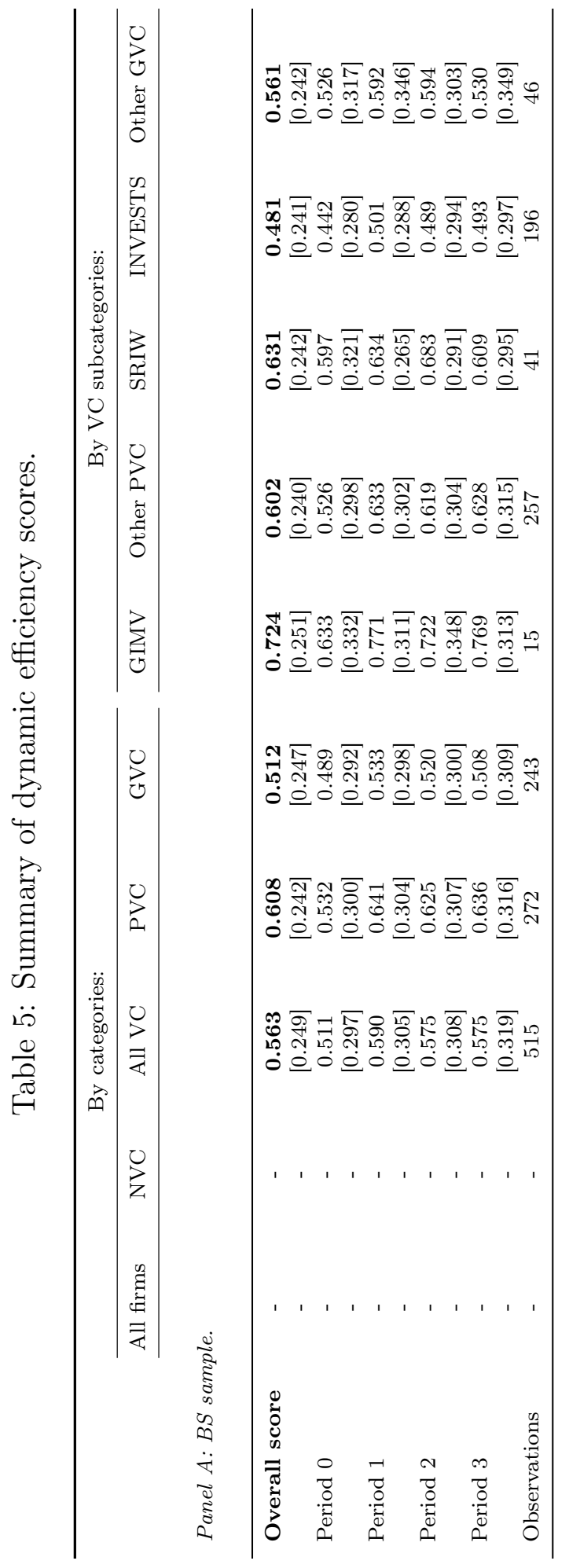

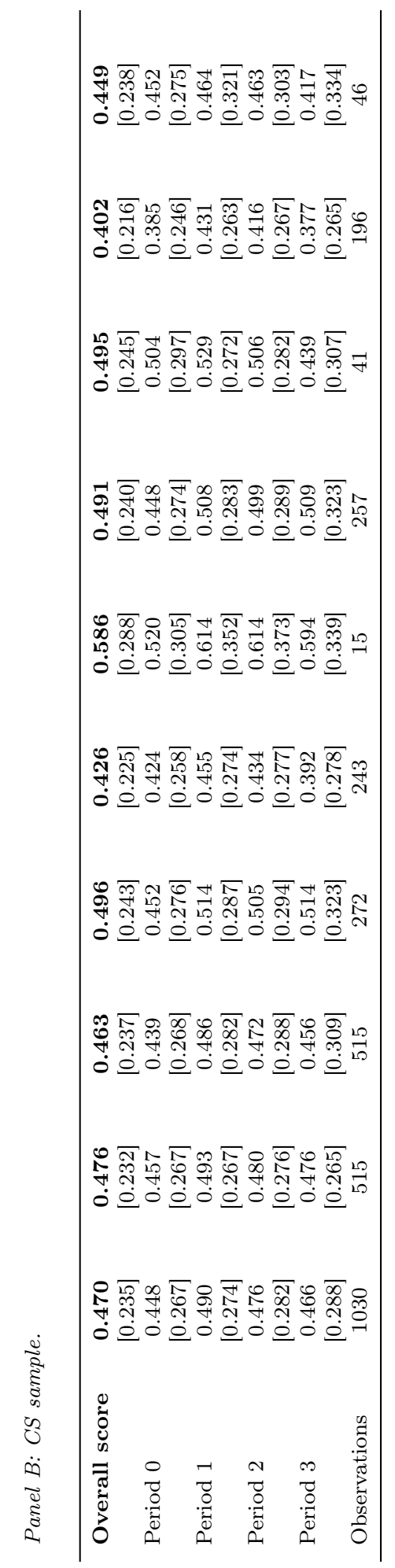

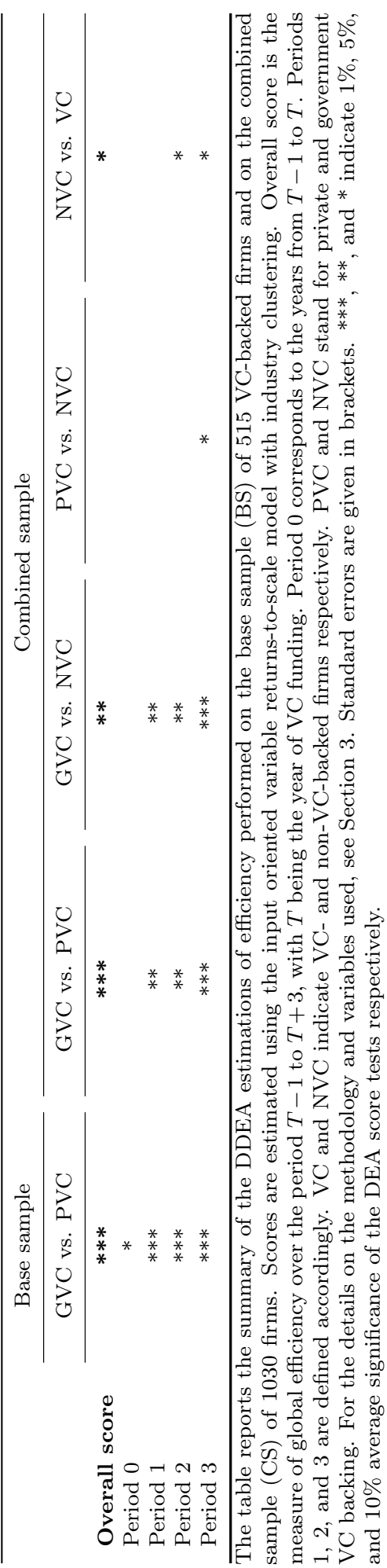


Table 6: Efficiency regressions using the base sample of 515 VC-backed firms.

\begin{tabular}{|c|c|c|c|c|c|c|c|}
\hline & (0) & (1) & $(2)$ & $(3)$ & (4) & $(5)$ & (6) \\
\hline $\mathrm{PVC}$ & & $0.285^{* * *}$ & & & & & \\
\hline SRIW & & & -0.007 & & & & -0.002 \\
\hline GIMV & & & & $0.568 * * *$ & & & $0.437^{* *}$ \\
\hline INVESTS & & & & & $-0.384^{* * *}$ & & $-0.378 * * *$ \\
\hline Other GVC & & & & & & 0.042 & -0.089 \\
\hline Age, $\mathrm{T}-1$ & -0.007 & -0.007 & -0.007 & -0.007 & -0.012 & -0.007 & -0.012 \\
\hline ROA, T-1 & $-0.076 * * *$ & $-0.067 * *$ & $-0.076 * * *$ & $-0.077^{* * *}$ & $-0.062 * *$ & $-0.077^{* * *}$ & $-0.061 * *$ \\
\hline Leverage, $\mathrm{T}-1$ & $-0.738^{* * *}$ & $-0.642 * * *$ & $-0.739 * * *$ & $-0.759 * * *$ & $-0.588^{* * *}$ & $-0.741 * * *$ & $-0.602 * * *$ \\
\hline Herfindahl index, T-1 & $0.462 *$ & $0.422 *$ & $0.462^{*}$ & $0.473^{* *}$ & 0.294 & $0.449^{*}$ & 0.333 \\
\hline Number of rounds & 0.051 & 0.016 & 0.051 & 0.025 & 0.018 & 0.052 & -0.005 \\
\hline Syndication & 0.063 & -0.008 & 0.064 & 0.030 & 0.083 & 0.061 & 0.061 \\
\hline Industry dummies & Yes & Yes & Yes & Yes & Yes & Yes & Yes \\
\hline Constant & Yes & Yes & Yes & Yes & Yes & Yes & Yes \\
\hline$R^{2}$ & 0.168 & 0.202 & 0.168 & 0.185 & 0.226 & 0.168 & 0.238 \\
\hline N.obs. & 515 & 515 & 515 & 515 & 515 & 515 & 515 \\
\hline RESET1, p-val. & 0.133 & 0.666 & 0.135 & 0.363 & 0.827 & 0.130 & 0.706 \\
\hline RESET2, p-val. & 0.158 & 0.819 & 0.153 & 0.594 & 0.893 & 0.151 & 0.929 \\
\hline GOFF1, p-val. & 0.150 & 0.651 & 0.152 & 0.379 & 0.812 & 0.146 & 0.701 \\
\hline GGOFF, p-val. & 0.150 & 0.651 & 0.152 & 0.379 & 0.812 & 0.146 & 0.701 \\
\hline \multicolumn{8}{|c|}{ Average partial effects. } \\
\hline \multicolumn{8}{|l|}{$\mathrm{VC}$} \\
\hline PVC & & $0.099^{* * *}$ & & & & & \\
\hline SRIW & & & -0.002 & & & & -0.001 \\
\hline GIMV & & & & $0.197 * * *$ & & & $0.150^{* *}$ \\
\hline INVESTS & & & & & $-0.132^{* * *}$ & & $-0.130 * * *$ \\
\hline Other GVC & & & & & & 0.015 & -0.031 \\
\hline
\end{tabular}

The table reports regressions of efficiency scores on the variables of interest and controls using the base sample of 515 VC-backed firms. Wooldridge-Papke estimator for fractional response variables is used for all models. Coefficients are estimated with robust standard errors. $* * *, * *$, and $*$ indicate $1 \%, 5 \%$, and $10 \%$ significance respectively. RESET 1 , RESET2, GOFF1, and GGOFF lines provide the p-values of the model specification error tests and functional form specification error tests (Ramalho et al., 2011, 2010; Murteira and Ramalho, 2013; Ramalho et al., 2013).

Table 7: Efficiency regressions using the combined sample of 1030 firms.

\begin{tabular}{|c|c|c|c|c|c|c|c|c|}
\hline & $(0)$ & $(1)$ & $(2)$ & (3) & $(4)$ & $(5)$ & (6) & (7) \\
\hline $\begin{array}{l}\text { Industry dummies } \\
\text { Constant }\end{array}$ & $\begin{array}{l}\text { Yes } \\
\text { Yes }\end{array}$ & $\begin{array}{l}\text { Yes } \\
\text { Yes }\end{array}$ & $\begin{array}{l}\text { Yes } \\
\text { Yes }\end{array}$ & $\begin{array}{l}\text { Yes } \\
\text { Yes }\end{array}$ & $\begin{array}{l}\text { Yes } \\
\text { Yes }\end{array}$ & $\begin{array}{l}\text { Yes } \\
\text { Yes }\end{array}$ & $\begin{array}{l}\text { Yes } \\
\text { Yes }\end{array}$ & $\begin{array}{l}\text { Yes } \\
\text { Yes }\end{array}$ \\
\hline $\begin{array}{l}R^{2} \\
\text { N.obs. }\end{array}$ & $\begin{array}{l}0.098 \\
1030\end{array}$ & $\begin{array}{l}0.103 \\
1030\end{array}$ & $\begin{array}{l}0.101 \\
1030\end{array}$ & $\begin{array}{l}0.099 \\
1030\end{array}$ & $\begin{array}{l}0.102 \\
1030\end{array}$ & $\begin{array}{l}0.129 \\
1030\end{array}$ & $\begin{array}{l}0.098 \\
1030\end{array}$ & $\begin{array}{l}0.133 \\
1030\end{array}$ \\
\hline \multicolumn{9}{|c|}{ Average partial effects. } \\
\hline $\begin{array}{l}\text { VC } \\
\text { PVC } \\
\text { SRIW } \\
\text { GIMV } \\
\text { INVESTS } \\
\text { Other GVC }\end{array}$ & & $-0.042^{* *}$ & $0.032 *$ & -0.035 & $0.122^{* *}$ & $-0.118^{* * *}$ & -0.016 & $\begin{array}{l}-0.023 \\
0.093 \\
-0.117^{* * *} \\
-0.038\end{array}$ \\
\hline
\end{tabular}


${ }_{861}$ B Appendix

\section{B.1 The Belgian venture capital industry}

\section{B.1.1 Global activity over the 1998-2007 decade}

The Belgian venture capital industry is quite well developed (Manigart et al., 2002). It experienced a relatively volatile decade over the period from 1998 to 2007. According to the European Private Equity \& Venture Capital Association (EVCA) and the Belgian Private Equity \& Venture Capital Association (BVA) statistics, funds raised and invested at the beginning of the decade had, until the year 2000, been on the increase. More than $€ 645$ million was raised in the industry that year. In the following year, according to the EVCA, the fundraising fell to as low as $€ 134$ million. No apparent reason was given in the yearbooks about this drop. Note that during this period EVCA did not provide data by fund stage focus, thus we are unable to distinguish which funds were raised for buyout purposes and which for $\mathrm{VC}$ investing. The fundraising gradually grew to about $€ 210$ million in 2004, followed by another drop in 2005 to $€ 120$ million. The amount of funds raised in 2006 skyrocketed to $€ 614$ million and fell again to $€ 144$ million in 2007 . During its best year (2006), the size of the industry roughly accounted for $0.299 \%$ of the GDP (according to the industry statistics). The major sources of these funds in 2001 were the government agencies and banks (more than 90\%). This proportion gradually decreased to $55 \%$ in 2007.

The total amount of funds invested in 1998 was $€ 258$ million. Almost half (about 46\%) of these investments were made by the public sector. Investments flourished in the following year rising to as high as $€ 670$ million. After this peak, they gradually declined to about $€ 193$ million in 2005. The years 2006-2007 showed some surprising jumps in investments - €940 million in 2006 and more than $€ 1$ billion in 2007. Interestingly, the EVCA statistics show that the public sector's share of total VC investments, in terms of amounts invested, sharply declined from $48 \%$ in 2002 to about $8 \%$ in 2003 , and slumped to about $2 \%$ in 2007 . No reason was provided in the yearbooks to explain this variation. All these figures should be regarded with caution, since the EVCA compiled them based on the information disclosed by its members. This disclosure is non-mandatory, hence 
may not be fully accurate.

As for the distribution of Belgian VC investments by sector during the sample period, the major portion of the invested funds is directed to the consumer goods, retail, and services sectors (around 26\% on average between 1998 and 2007). The second largest sector is business and industrial products \& services (20\%), followed by the life sciences and biotechnology (15\%). The biotech investments were dominant in 2005 (34\%) whereas in later years there has been a shift towards more traditional sectors.

\section{B.1.2 Structure of the venture capital playing field}

Belgium is characterized by a fairly high proportion of investments made by public funds. Two big categories of public funds can be distinguished: (i) the regional funds (SRIB, SRIW, PMV, and formerly, GIMV), and (ii) the local reconversion funds (in the old-fashioned industrial basins).

In the wake of post-WWII measures aiming at modernizing the Belgian economy, the center-left government created a public fund in 1962 - the National Investment Company (NIC) - in order to alleviate the difficulty of smaller businesses to access financing sources, especially bank loans (Bayenet, 1996). Ten years later, in response to the global oil crisis, the NIC received considerable additional means from the state.

However, divergent views appeared soon between booming Flanders, where most of the multinational companies were established, and declining Wallonia, confronted with the rapid decline of its coal and steel industries. The situation ended up with the regionalization of economic competencies in 1979 and the consequent split of the NIC into two regional funds: SRIW in Wallonia and GIMV in Flanders. The Brussels counterpart (SRIB) was incorporated five years later along with the decision to create a third region (Brussels-Capital).

As a reaction to the dramatic job losses in the coal and steel industries in the early eighties, the regions set up local investment funds dedicated to the reconversion of the old industrial sectors. One fund in Flanders (Limbourg) and three funds in Wallonia (Liège, Charleroi and Walloon Brabant) were initiated. These local funds (the so-called "INVESTS") are public-private structures receiving their financial means from the regions. Their commitment is limited to $€ 1.25$ million per 
investment in a local SME (provided the company is not linked to a larger group). According to the then prevailing "compensation principle" (a principle that implies that whenever one sub-region receives financing or other benefits from the regional or federal governments, other sub-regions have to receive an equivalent "compensation", i.e. funding, from the authorities), five additional local investment structures were created in 1988 and 1989 in the other non-industrial Walloon areas (in West and Central Hainaut, in the provinces of Namur and Luxembourg and in the German-speaking part of Walloon region).

From the beginning, SRIW and SRIB on the one side and GIMV and the others took different paths. Due to financial constraints, the Flemish policy-makers decided not to support local companies and industries if they had not proven their businesses to be viable. In the same vein, the limitation of the endowments to the GIMV itself - while keeping the same policy targets - implied three major consequences. First, the GIMV had to become more self-sufficient, i.e. generate more cash flows by increasing efficiency in screening and in managing participations (hands-on) and by achieving a higher portfolio turnover (shorter period of investment). In order to do so, GIMV recruited new team members with a mix of entrepreneurial and consulting profiles. Along with these initiatives, GIMV decided to liquidate lame ducks from its portfolio at high cost. Secondly, the lower government's commitment needed to be compensated by private funds. With this aim in mind, GIMV sought leverages from private investors - especially foreign funds - through syndications. As a consequence, GIMV investment managers were asked to develop international contacts and strengthen the legitimacy of GIMV on the international markets. Finally, it resorted to new sources of funds by becoming listed on the Brussels stock exchange. The interplay of these factors gradually transformed GIMV into essentially a private VC fund.

Unlike the Flemish Government and the GIMV, the Walloon and the Brussels Governments have until now maintained the three original strategic goals of SRIW and SRIB: (i) financing the growth of companies, (ii) supporting business creation, and (iii) carrying-on interventions on the government's behalf. SRIW was organized in multiple funds according to the industries they addressed, resulting in quite a complex structure.

The boom of internationally oriented local SMEs combined with the creation of a second market 
at the Brussels stock exchange, and a fiscally favorable business environment (no capital gains tax) led to the establishment of the first private funds in Belgium in the mid-eighties. These funds were mainly set up by the initiative of large domestic banks (KBC's Investco, Générale de Banque's VIV, and Synerfi) and big foreign funds (Advent, Benevent and Euroventures). Unfortunately, the momentum was soon lost with the economic collapse of Black Monday (October 1987). Public funds found themselves in a quasi-monopolistic situation again, until the mid-nineties. During that period, direct public investment was significantly increased, especially in Limburg and in the Walloon provinces, through the local "INVESTS".

The second half of the nineties saw the advent of a new wave of private funds on the market, encouraged by local investors and operating through the classic VC dual structures. These new funds (Trustcapital, Creafund, E-Capital, FLV Fund, etc.) were more focused on early stages (technology start-ups) and on firms located in Flanders. In Wallonia, this role was played by the local "INVESTS". The resulting VC market made ambitious projects possible such as Telenet (now the largest Flemish telecom operator) or Devgen (health care company located in Ghent, now called Syngenta).

The burst of the Internet bubble in the early 2000s abruptly interrupted the VC market growth. A large number of the second-generation funds simply went off the radar while others, better capitalized, barely managed to survive. In such a context, during the first part of the decennia, public funds supplied most of the investments in SMEs. In this context, the Walloon Regional Government decided to sort out the various overlapping and competing activities of the public funds. This was achieved by implementing strict investment rules and by placing the local "INVESTS" under the guardianship of an umbrella structure, the Sowalfin, in 2002.

All Belgian public funds now operate simultaneously as equity and debt providers. Aside from the classical long-term loan packages, public funds also provide convertible and subordinated debt facilities. No precise figures are published about any breakdown of the funds used, neither about their returns. It is assumed that loans are increasingly preferred to equity as public funds are required to take only minority participations in companies. In many cases, it has been proven difficult for them to plan for any exit of their stakes. Consequently, vast amounts of money have 
sometimes been trapped in portfolio companies for very long periods of time.

The public funds are usually poorly capitalized. Their main source of funds comes from drawing rights granted by the regional authorities. A recent (and probably imprecise) estimation of the financial resources of the Belgian public funds was conducted by the SRIB in 2011 at the request of the Brussels regional authorities. As such, SRIB reports that Flemish public funds manage a total of $€ 1038$ million ( $0.50 \%$ of the regional GDP in 2011), split between LRM (€247 million) and PMV (€791 million). At the same time, Brussels's own public VC fund disposes of about /euro 161 million (0.23\% of the regional GDP in 2011). Finally, the Walloon region has a total of $€ 1690$ million available (1.96\% of the regional GDP in 2011) split between SRIW (€963 million), "INVESTS" (€625 million), and CIW (Caisse Wallonne d'Investissement, €102 million). The Walloon Region has created two additional investment vehicles that are not taken into account in the present paper. The first one is Sowalfin, created in 2002 primarily involved in providing guarantees on bank loans granted to SMEs (€167 million). The second is the Sogepa fund, which operates on behalf of the Walloon Government in the distressed company segment (€177 million).

\section{B.2 Treatment of the missing data}

Bel-first introduces a considerable amount of missing data in our sample. This is problematic for the DEA methods as they require a balanced panel data structure. One of the reasons for this $\mathrm{N} / \mathrm{A}$ issue is that startups are allowed to report first-time financial statements after more than twelve months. If this occurs it creates a missing item for the creation year. In such cases we correct the first-year items on a pro-rata basis.

Liquidated, bankrupt, or completely sold out companies also result in N/A data for the corresponding observations. Roughly, these cases correspond to the exits by venture capital investors of their stakes. Remember that our analyses are related to the $T-1 / T+3$ time window around the transaction date $T$. Therefore the missing data issue is only relevant for the data points within this interval. We consequently checked the exits occurring before the end of the third post-transaction year. Three targets were exited and twenty five were liquidated in a bankruptcy procedure during 

1011

the period $T-1 / T+3$. This amount constitutes a negligible proportion of less than $2 \%$ of the total number of firms in the raw sample. All remaining firms may have gone bankrupt or been exited after $T+3$ year.

Finally, we noted that Bel-first reproduces accounting items as is. This means that if a company reports a zero or blank field for a given item (e.g., financial debt), Bel-first records them in the same way, leading to another N/A issue. We thus manually investigated the structure of such missing data together with the status of the sample firms. It appeared that all the companies concerned were reported as active. In addition to that, the missing/blank patterns proved to be unsystematic from one variable to another. Therefore, for the unambiguous cases, we safely inferred zero values out of blanks. Whenever it was not possible, we used a conservative approach, in which we allowed one blank data point per variable. If it occurred on the bounds of the $[T-1, T+3]$ interval, we used a simple trend line to forecast its value. If it occurred within the stated bounds, we averaged two adjacent non-missing data points to substitute for the blank item.

After applying all these filters and corrections, our final sample, denoted the base sample (BS), consists of 515 VC-backed companies, for which we have complete data to perform all efficiency estimations. 